This PDF is a selection from an out-of-print volume from the National Bureau of Economic Research

Volume Title: The Role of Direct and Indirect Taxes in the Federal Reserve System

Volume Author/Editor: NBER and The Brookings Institution

Volume Publisher: Princeton University Press

Volume ISBN: 0-87014-469-3

Volume URL: http://www.nber.org/books/unkn64-4

Publication Date: 1964

Chapter Title: Equity, Administration and Compliance, and Intergovernmental Fiscal Aspects

Chapter Author: Douglas H. Eldridge

Chapter URL: http://www.nber.org/chapters/c1875

Chapter pages in book: (p. 141 - 215) 


\title{
Equity, Administration and Compliance, and Intergovernmental Fiscal Aspects
}

\author{
DOUGLAS H. ELDRIDGE
}

\author{
CLAREMONT MEN'S COLLEGE
}

\section{Equity Considerations}

TAX equity is the distribution of burden among taxpayers in a manner regarded as fair. Evaluation of taxes on equity grounds requires a knowledge of where the tax burden falls upon individuals or taxpaying units, some criterion of taxpaying capacity against which the burden is compared, and a judgment or consensus as to the manner in which burdens should vary with differences in such capacity.

Taxpaying capacity has been variously viewed in terms of wealth, income, faculty, or a general notion of ability to pay which may take into account not only the taxpayers' wealth or income but differences in circumstances with respect to family, age, and sources and uses of income. A criterion of individual taxpaying capacity widely accepted by tax students is personal income as defined by Henry C. Simons: "the algebraic sum of (1) the market value of rights exercised in consumption and (2) the change in the value of the store of property rights between the beginning and end of the period in question." serve as a point of departure. Much of the debate about tax fairness concerns the relationship of tax burdens to income. Federal income tax changes are judged according to the equity of their redistribution of the tax burden among individuals' income levels. Also, in comparisons of different forms of taxation, relative burden distributions are typically related to income, and fairness is judged by proportionality, regressivity or progressivity with respect to individual income. ${ }^{2}$

So far as equity among individuals is concerned, the personal income tax seems superior to indirect taxes. Personal income taxes may have

${ }^{1}$ Personal Income Taxation, Chicago, 1938, p. 50.

${ }^{2}$ Cf. Richard A. Musgrave, The Theory of Public Finance, New York, 1959, p. 164 and passim in discussion of differential incidence. Nicholas Kaldor, as Musgrave points out, advocates a progressive spending tax and defends it by arguing that it need not be less progressive in terms of income than an income tax (see Nicholas Kaldor, An Expenditure Tax, London, 1955). See also David G. Davies, "Commodity Taxation and Equity," Journal of Finance, December 1961, pp. 581590 ; "Progressiveness of a Sales Tax in Relation to Various Income-Tax Bases," American Economic Review, December 1960, pp. 986-995; and "An Empirical Test of Sales Tax Regressivity," Journal of Political Economy, February 1959, pp. 72-78. 
their income and substitution effects relative to work vs. leisure or consumption vs. saving but after any adjustments are worked out, the individuals' tax liabilities and incomes are known and meaningful comparisons may be made. While personal income taxes may to some extent be shifted, these effects are small as compared to the shifting possibilities of indirect taxes.

Nonetheless, the view has developed that indirect taxes may be levied with considerable precision as to burden distribution among individual income levels.

Research studies have demonstrated that the general sales tax need not be regressive, defining the term "regressive" as the taking of a rising proportion of decreasing income. By manipulation of exemptions it is possible to make the sales tax regressive, proportional or even progressive. . . . We need no longer think of the sales tax as hitting the poor man and the income tax as hitting the rich man. The taxes are, or can be, virtually interchangeable on that score, with proper adjustment of detailed provisions. $^{3}$

This view rests on assumptions about the incidence of sales taxes and an accuracy in allocating burdens among individual income classes that seem questionable. In my estimation, greater reliance on indirect taxation necessarily means resort to much cruder and less reliable tools for achieving tax equity. If the shift were to take the form of greater use of selective sales taxes, part of the burden of the federal tax take would be redistributed among individuals as income earners and as consumers or income users. Since the process of either forward shifting or backward shifting of such a tax is not likely to be smooth and uniform throughout the economy, it would be extremely difficult to attribute the total tax burden to particular individuals or income levels. Greater reliance on a general indirect tax, rather than on selective sales taxes, presumably would involve less uncertainty concerning the change in the distribution of tax burdens among individuals or income levels. In practice, however, there are no truly general indirect taxes. A substantial shift from the income tax to indirect taxes, therefore would result in changes in the distribution of tax burdens with respect to individuals' income sources, as well as uses in the private sector of the economy. A considerable part

${ }^{3}$ Harold M. Somers, "Theoretical Framework of Sales and Use Taxes," Proceedings of the National Tax Association for 1961, p. 615, referring to David G. Davies' article in Journal of Political Economy, February 1959. See also Ronald Robertson, "What Do We Want of Our Tax System," Canadian Tax Journal, July-August 1962, pp. 233-234. 
of this redistribution would, in the present state of knowledge, have to be regarded as haphazard and uncertain.

To evaluate the equity effects of a shift to indirect taxes, the concept of differential tax incidence seems most useful. ${ }^{4}$ This reflects the difference in burden distribution among individuals of two forms of taxes which would provide the government equal yields in real terms; the amount of the economy's resources being utilized by government remains unchanged, and attention can be directed to the changes that result in individuals' real incomes from the substitution of taxes. For those individuals who suffer a reduction in real income from the tax change, the additional tax burden may be in the form of a reduction of the incomes they receive (the income sources side) or a reduction in the volume of goods and services that they obtain because of changes in relative prices (the income uses side).

In estimating the distribution of sales tax burdens among individuals, it is often assumed that the tax is passed forward by the business firms and is borne by the ultimate consumer. ${ }^{5}$ With this convenient assumption, total sales tax yields may be attributed to consumers according to estimated expenditures on taxed items. The assumption, however, has serious limitations as a basis for judging the redistributional effects of a substantial replacement of income taxes by indirect taxes.

The assumption that sales tax burdens can be wholly allocated to consumers implies that all of the significant effects of a shift from income to sales taxes occur on the income uses side of individuals' real income positions. This can hardly be true for a substantial change in the form of federal taxes, except possibly in the very long run.

The issues involved in this connection have been extensively discussed in the literature during the last fifteen years and will not be reviewed in detail in this paper. A few summary observations will suffice:

1. In an all-consumption competitive model there is equivalence of incidence of general taxes. ${ }^{6}$ Either form of tax-general income or general indirect-reduces the amount of funds available for payments to

${ }^{4}$ Cf. Musgrave, Theory of Public Finance, pp. 211-213. I am also indebted to George Break, Earl Rolph, and Procter Thomson for helpful comments.

'See, for example, David G. Davies' articles in American Economic Review, December 1960, p. 987, and in Journal of Political Economy, February 1959, p. 72. See also, Irving J. Goffman, The Burden of Canadian Taxation, Toronto, 1962, p. 41; and William H. Hickman, Distribution of the Burden of California Sales and Other Excise Taxes, Sacramento, 1958, p. $42 ;$ R. A. Musgrave, "The Incidence of the Tax Structure and Its Effects on Consumption," in Federal Tax Policy for Economic Growth and Stability, papers submitted to the Joint Committee on the Economic Report, U.S. Congress, Washington, 1955, p. 101.

${ }^{6}$ Musgrave, Theory of Public Finance, Chapter 15. 
productive factors. Since in this model all individuals are both consumers and income recipients to the same magnitude, either tax may also be thought of as falling on consumers or on income recipients.

2. In a capital-formation, competitive model, a general indirect tax applicable to all firms-those producing capital goods as well as those producing consumption goods-is equivalent to a general income tax, applicable to all factor payments. An indirect tax applicable only to consumption items, however, will at the least differ from the general income tax on the income uses side and may differ as well on the income sources side, in the short run.

3. The substitution of selective or partial indirect taxes for general taxes will change the composition of output and relative factor payments. The nature of these changes will depend on the production functions in the industries producing the taxed and untaxed items, the elasticities of demand for the taxed and untaxed items, and the elasticities of the supplies of the factors of production in the taxed and untaxed industries. $^{7}$

With these summary observations in mind, what are the implications for vertical tax equity of greater reliance on indirect taxes?

In the case of selective indirect taxes, it has been suggested that it may be necessary to ignore their differential burdens on the income sources side in considering vertical tax equity. Musgrave, for example, has noted that with a shift from general to discriminatory taxes, there will be changes in relative factor prices and income receipts, but the distributional implications are unclear. ${ }^{8}$ No a priori conclusion seems possible as to whether the individuals who gain or lose are at low, middle, or high income levels. Musgrave hypothesizes that a random distribution of factor gains or losses among individual income classes will occur and, hence, the effect of the tax change is assumed to be neutral with respect to income sources. The need for empirical investigations to check the simplifying hypothesis is acknowledged, but for the time being its use points to the conclusion that the effects on income sources may be ignored, and the differential incidence of selective sales taxes depends on income uses for taxed and nontaxed products.

Musgrave's analysis is cited as justification for the view that selective indirect tax burdens are borne in relation to individuals' expenditures. ${ }^{9}$ But this view has obvious limitations. It is true that available data are

${ }^{7}$ Cf. Arnold C. Harberger, "The Incidence of the Corporation Income Tax," Journal of Political Economy, June 1962, pp. 215-240.

8 Theory of Public Finance, pp. 357-359.

${ }^{\circ}$ See, for example, John F. Due's introductory paper to this conference volume. 
much better with respect to consumer budget patterns than for measuring relative tax-induced changes in factor shares. The differential incidence of selective taxes on the income uses side for individuals can be attributed to income levels on the basis of studies of expenditure patterns. In this sense we can say that what is more readily known about the burden distribution of partial sales taxes is based upon expenditure data. But one may be skeptical about the hypothesis that the portion of differential burden attributable to income sources is distributed neutrally among income classes. And even if the simplifying hypothesis is tentatively accepted, it gives only crude results for evaluating equitable burden distributions among individual taxpayers. The effect of a shift to a selective tax may be to raise A's income and lower B's, and the inequity of this disparity is not changed if both are relatively high or low in the income scale and the effects are assumed to cancel out for the whole income class. Fundamentally, equity relates to tax treatment of individuals and not abstract average treatment of broad income classes.

Moreover, to the extent that there are redistributional effects of selective taxes on the income sources side for individuals, there is less differential burden to attribute to them as income users. Insofar as a tax change reduces factor earnings or monopoly profits in taxed industries relative to those in nontaxed industries, there is no tax-induced change in the relative prices of products. A simple allocation of a selective indirect tax according to individual expenditure patterns is likely to be quite far from the mark.

The redistributional effects of replacing direct income taxes with indirect taxes will differ with the form of indirect tax employed. The principal candidates appear to be a general retail sales tax or one of two forms of value-added taxes.

Conceptually, a general retail sales tax may be regarded as an indirect tax imposed on the sale of all consumption items. Actual retail sales tax bases typically do not apply to all final consumption expenditures and they do include some sales to businesses of items used in further production, including capital goods. But the general objective of this form of tax is to impose a single levy, at the final stage of production, on the price paid by the consumers.

The value-added taxes are imposed upon firms at each level of production according to their sales of products, but allowance is made for costs incurred in the purchase of goods from other firms, so that only the net value added at each production stage is subject to tax. The tax 
base for each firm would be its gross receipts from current output less payments to other firms for goods and services. On these latter items, tax is paid by the supplying firms. Thus, for consumption goods, the sum of the values added at each stage of production would be equivalent to the final value of the good to consumers.

In an economy with net investment or disinvestment, value-added taxes may be of different types depending upon the treatment of outlays for capital goods and inventories. ${ }^{10}$ An income variant of the valueadded tax conceptually has results similar to a general, flat-rate income tax; a consumption variant, similar to a general tax on all consumption items.

Under the income form of value-added tax, a firm's investment costs are not deductible as incurred. They are written off in determining the annual tax base, as the investment is consumed in the process of production. The difference between receipts and payments to other firms (except for net investment) reflects all the costs of factor payments, including implicit costs of firm-owned factors and profits. The tax burden will tend to be spread evenly over all incomes derived from private production, in a manner similar to a flat-rate income tax on individuals. Since the tax has to be covered by firm receipts, prices of factors will be lowered relative to the prices of products. With uniform tax shifting, the relative reduction will be proportional for all income sources. All product prices, including capital goods, are affected proportionately, and there will be no change in alternatives available on the income uses side for individuals or households. For the whole private economy, the accounting for value added equals current value of total net product or total factor payments, or a tax base equivalent to total income after capital consumption allowances.

Under the consumption form of value-added tax, a firm's investment in capital equipment or inventory is deductible in the year of purchase. The value added in the economy by capital goods industries is currently offset by deductions from value added by consumption goods industries year by year, but no subsequent deductions for investment items are allowed as they are used up in production. Over-all, the total value added by the various stages of production appears in the tax base as consumption goods are produced and sold. For the economy, the consumption value-added tax base approximates current consumption, or a general retail sales-tax base, and is smaller than the income value-added base by the amount of net current investment.

${ }^{10}$ Carl S. Shoup, "Theory and Background of the Value Added Tax," Proceedings of the National Tax Association for 1955, pp. 6-19. 
In a growing economy, a consumption value-added tax, like a general retail sales tax, will continuously have a smaller base than the income value-added tax, and higher tax rates would be required for equal revenue yields. The value of current consumption items covers the value added to them by productive factors in the current year plus the value added by capital goods used up in current production. In the over-all accounts, part of gross current value added is an offset to the exhaustion of previously produced capital assets, and total net product or total factor incomes continuously exceed consumption by the amount of net investment. Presumably an income tax could also be converted to a similar consumption basis by allowances for currently expensing all capital investments, in effect exempting current savings and investment.

While value-added taxes may be designed to achieve generally similar results to those of flat-rate income taxes or retail sales taxes, different tax impacts and shifting processes are involved which may affect particular tax burdens. To illustrate simply, assume A produces capital goods solely from labor inputs and sells the assets to $B$, who, with additional labor inputs, produces consumer items. A general income tax wedge directly reduces all factors' disposable incomes. An income valueadded tax puts the wedge between firm receipts and factor payments and is presumably shifted backward. A general retail sales tax puts the wedge between $B$ and consumers; the amount B pays A and his own factors differ from prices charged consumers by the amount of the tax. A consumption value-added tax is imposed on A when he sells capital goods and represents a wedge between A's current receipts and factor payments. However, A's tax is currently offset in the over-all accounts by B's tax savings through deduction for the full cost of assets. At the retail level, as final products are sold, a tax wedge is inserted equal to the tax rate times the full value added by both $\mathrm{A}$ and $\mathrm{B}$. The timing of remittances to the government differ for $\mathrm{A}$ and $\mathrm{B}$, but with tax shifting adjustments over time, the spread between consumer prices and all factor payments could be expected to be the same under the consumption value-added tax and the retail sales tax.

In some circumstances the value-added tax wedge confronting consumers at the retail level may differ from the sum of the value-added tax wedges at all levels of production. Value added by a firm can be computed either by deducting from the gross receipts all purchases from other firms (the subtraction method) or by adding all of the factor payments of the firm to individuals including implicit costs, i.e., wages, rent, interest and profits (the addition method). With capital investment or disinvestment for the firm, the subtraction method gives the consump- 
tion variant of value added, and the addition method gives the income variant. ${ }^{11}$ Suppose there is an unanticipated drop in the retail firm's product price, so that its gross receipts for the year do not cover the total costs of purchases from other firms and payments to its own factors; the retail firm incurs a loss. The subtraction method will give a value-added base for the firm of less than total costs. The total of all net value added at all levels of production will be equal to selling prices of final products, the same as the retail sales tax base. Under the addition method, the value-added base for the retail firm exceeds gross receipts, unless losses are deductible. If losses at the retail level decrease the final value-added base, the amount of the tax wedge between retailers and consumers may be less than the sum of the tax wedges previously remitted to the government by producers at several earlier, successive stages of production. In this situation either form of value-added tax has some of the aspects of a net income tax where the tax take from all firms exceeds the statutory rate on over-all net income or value added, since the loss of one firm does not reduce the tax base for others. In the value-added case the relative rise in prices to consumers over the amount paid to factors may be less than the total tax.

Either form of consumption tax, however, would exempt currently the use of funds for the purchase of capital goods. Persons who save and invest would be better off under these taxes than under the income tax or the income value-added tax.

The general effects of a shift from existing federal individual income tax to an income value-added tax would be to replace the direct elements of progression with an essentially proportional tax distribution to be achieved through tax shifting to factor payments. A shift to general consumption taxes-value-added or general retail sales taxes-would tend to make the burden distribution regressive with income, to the extent that the proportion of income saved tends to increase as income levels rise.

\section{CORPORATION INCOME TAXES AND VALUE-ADDED TAXES}

Corporation income taxes do not have a direct link with individual tax burdens. The distribution of these taxes among individuals appears more akin to sales taxes, with the indirect burden being shifted backward or forward in the same way as income sources or income uses are changed

${ }^{11}$ As Shoup has pointed out (ibid., p. 11), the addition method can be converted to the consumption variant by adding back depreciation charges and subtracting the entire amount of purchases for capital equipment and increased inventories. 
for individuals. The tax wedge at the corporate level applies to one complex type of factor return-profit, which for the most part is the return to equity capital. The general effect of the wedge is to reduce returns to capital relative to the prices charged for corporate products. ${ }^{12}$ Since the capital market tends to equalize the rate of return to all forms of capital (with allowances for risk) the post-tax return on corporate equity tends to equal the return on capital borrowed by corporations or used in the noncorporate sector. But corporate receipts must cover the gross return to equity capital as well as other factor payments, and product prices tend to be relatively higher than factor payments by the amount of the tax. Consumers' real incomes are affected on their uses side according to their relative consumption of corporate and noncorporate products.

On grounds of equity (as well as those of investment neutrality and of achieving an otherwise preferred combination of corporate and noncorporate products), elimination of the bias against corporate equity investment is desirable. A general value-added tax would be one means to this end, to the extent that it is borne uniformly on the income sources side by all types of productive factors and imposes a uniform wedge between factor returns and prices of final products. ${ }^{13}$

${ }^{12}$ As Harberger has shown, part of the tax incidence may in some instances fall on other factor returns. Imposition of the tax results in changes in the amounts consumers take of corporate and noncorporate products, relative contraction of corporate production, and a relative movement of productive resources from taxed to nontaxed fields. As in the case of selective sales taxes, there are complex considerations involved: (a) the elasticity of substitution for consumers between corporate and noncorporate products; (b) substitutibility between equity capital and other productive factors in both the corporate and noncorporate areas. Harberger's analysis indicates that on the income sources side, "It is hard to avoid the conclusion that plausible alternative sets of assumptions about the relevant elasticities all yield results in which capital bears very close to 100 per cent of the tax burden." Arnold C. Harberger, "The Incidence of the Corporation Income Tax," Journal of Political Economy, June 1962, p. 234; see also his paper "The Corporation Income Tax: An Empirical Appraisal," U.S. Congress, House of Representatives, Committee on Ways and Means, Tax Revision Compendium, Washington, 1959, pp. 231-250.

${ }^{13}$ See ibid., pp. 247-248. The corporate net income tax is also regarded as penalizing the efficient as compared to inefficient corporations, and for this reason the value-added $\operatorname{tax}$ has been proposed as at least partial substitute for the corporate income tax. (Cf. Dan Throop Smith, statement submitted to U.S. Congress, House of Representatives, Committee on Ways and Means, hearings on President's 1969 Tax Message, pp. 1069-1072, and his Federal Tax Reform, New York, 1961, p. 188.) This shift would impose some tax on corporations not earning net incomes and make it more difficult for them to stay in business and would lessen taxes for profitable companies, enabling them to expand more readily. The tax wedge would then be between all corporate receipts and all corporate factor payments, and in the aggregate all factor payments would be lower than corporate receipts by the same amount of tax if revenue yield were kept equal. This proposal would not eliminate 
Replacing the present corporate tax with a value-added tax would raise some troublesome problems. There would be greater need for major reforms to bring corporate earnings currently into individual income tax account. Otherwise the economic distortion against corporate investment would be replaced by strong distortions in the opposite direction. Even at present the general double tax bias against corporate investment may be offset for high bracket individual taxpayers by the favorable treatment allowed capital gains. On earnings retained at the corporate level, the corporation tax applies currently and the amount available for reinvestment is the earnings less the corporate tax (presently 48 cents on the dollar, as compared to 25 cents for the individual in the 75 per cent bracket who invests and reinvests in sole proprietorships or partnerships). The larger amounts of earnings available for reinvestment at the corporate level have the advantage of partial tax deferment. If these retained earnings plus accumulation on them are subsequently realized by the individual by sale of some of his shares, ${ }^{14}$ the double tax on the accumulated earnings consists of the corporate $\operatorname{tax}(52$ per cent) and the long-term capital gains tax on the amount left after corporate tax (25 per cent $\times 48$ per cent, or 12 per cent) so that the combined tax is 64 per cent instead of the individual's marginal rate on other income of, say, 75 per cent. The double tax on current corporation payouts of investment earnings, as has often been demonstrated, ${ }^{15}$ results in a differential tax burden on shareholders that greatly exceeds individual marginal tax rates at the lower bracket levels and narrows for individuals in the higher tax brackets. But the double tax on investments in corporations realized as capital gains creates a differential in favor of corporate investment for individuals with marginal rates above 64 per cent. ${ }^{16}$ If there were no corporate tax, and earnings in corporations could be brought to the individual subject only to exist-

tax differentials between corporate and noncorporate sectors. Whether a reduction of all corporate factor payments relative to the noncorporate would tend to contract corporate output more or less than a relative reduction only for corporate equity capital depends again upon the elasticity of substitution between capital and other factors in both sectors. If losses were deductible in computing value added, profitable companies would still suffer some discrimination, though in much lesser degree than under the corporate net income tax.

${ }_{14}$ This assumes that the market price of the stock accurately reflects the value of retained earnings.

${ }^{15}$ Perhaps most completely by Daniel M. Holland, The Income-Tax Burden on Stockholders, Princeton University Press for National Bureau of Economic Research, 1958.

${ }^{16}$ For investments in small corporations subject to a 30 per cent corporate rate, the tax differential in favor of corporate investment and capital gains begins to operate for individuals with marginal rates above 46.2 per cent instead of 64 per cent. 
ing capital gains treatment, the bias in favor of corporate over noncorporate investment would be represented by the difference between a 25 per cent tax and a 91 per cent tax for an individual in the top individual rate bracket. Even the individual in the 20 per cent individual bracket could halve his tax on capital earnings by investing in the corporate instead of the noncorporate area.

The existing income tax system has shortcomings from the standpoints both of investment neutrality and individual equity. Without the corporate tax, however, both neutrality and equity would seem to require bringing corporate earnings fully into individual tax account. This is likely to involve revenue losses, a lessening of the progressivity of the individual rate structure, and new types of administrative problems.

Conceptually, corporate earnings could be currently attributed and taxed to individual shareholders on a partnership basis. The difficulties in this approach are well known and do not require restatement. No other method, however, would afford complete equality of income tax treatment of corporate and noncorporate profits.

Replacement of the corporation income tax by a general value-added tax would thus involve reappraisal of the individual income tax structure. And the problems of equitable burden distribution would not be reduced significantly by the suggestion that the yield of the value-added tax could be raised sufficiently to provide a revenue margin for individual rate adjustments to achieve more or less over-all progression.

Conceptually at least, the burden of an income value-added tax is proportional to income. If introduction of a value-added tax were to be complemented by changes in individual income tax to establish some over-all degree of progressivity, the complementary changes in individual rate schedules might just as well be undertaken within the income tax itself rather than raising the value-added tax to provide revenue leeway for additional individual income tax adjustments. The valueadded tax shifts the over-all burden closer to proportionality. To attempt to compensate for the value-added tax in low income brackets and to restore or maintain over-all progression would apparently mean more steeply rising individual rates, especially through the middle brackets, than now exist.

A general value-added tax in lieu of the corporate income tax would also generalize the problems of "double taxation" and of integrating business and personal taxes, for a tax would then be imposed at the business level for noncorporate as well as corporate organizations ac- 
cording to the value of all productive factors directly employed by the firm. If it is desired to remove tax biases against corporate profits and reform the distribution of individual tax burdens, this goal might better be approached by directly modifying the individual income tax and concentrating corporate tax reform efforts toward integration of the two levels of taxes, so that the combination neither markedly augmented nor diminished individual income tax liabilities.

\section{ADJUSTMENT OF THE TAX BASE}

The regressive character of consumption taxes with respect to uses of income can be modified by employing selective tax bases. The adjustments that can be made in the distribution of tax burdens, however, must be of a broad and general type that operate imprecisely for particular individuals.

Empirical studies of state sales taxes attributed to consumers at various income levels show that the indicated regressivity of broad retail sales taxes gives way in some income ranges to proportionality, or a degree of progressiveness with the exclusion of various items from the base. ${ }^{17}$ The principal factor is food purchased for home consumption. This is a major budget item which usually declines in relative importance as income levels rise. Exemptions of household utilities (water, gas and electricity), gasoline, and newspapers and periodicals were also found to lessen regressivity. On the other hand, the exemption of restaurant meals as well as food tended to make burden distributions slightly more regressive than when only take-home food was exempt. Davies' assumptions and calculations of burdens for the several sales tax states that exempt food indicated that about half of the consumer units were subject to some progression when the estimated burdens were compared with incomes, but he regarded the over-all burden distribution as basically regressive. ${ }^{18}$

These findings, while helpfully illuminating, do not warrant conclusions that sales taxes can be made facile and accurate instruments for vertical tax equity. A legislative effort to design a sales tax base to achieve some desired degree of progression would encounter a number of problems.

The assignment of indirect tax burdens in proportion to consumer

\footnotetext{
${ }^{17}$ Reed R. Hansen, "An Empirical Analysis of the Retail Sales Tax with Policy Recommendations," National Tax Journal, March 1962, pp. 1-13; and the previously cited studies by William Hickman and David G. Davies.

18 "Commodity Taxation and Equity," p. 588.
} 
expenditures on taxed items is only as valid as the incidence assumptions. The entire burden of selective sales taxes is not likely to be on consumers. Even if the sales tax base could be narrowed to items generally consumed proportionately or progressively with income levels, the full burden distribution could not confidently be assumed to be distributed in the same ratios.

The relating of indirect tax burdens and individual incomes is based upon surveys of incomes, savings and expenditures of consumer units. The income and spending data obtained appear in many instances to be a good deal less reliable than information reported on income tax returns. In calculating the average income, expenditure patterns, and tax burdens, a number of adjustments must usually be made and the final estimates probably have a considerable margin of error. ${ }^{19}$

The amount of indirect tax burdens assumed to fall on particular individuals or households can be only a general approximation when estimates are based on averages from sample studies. Data derived from budget surveys represent average expenditures for taxed and nontaxed categories of goods and services for all family units falling in designated money income classes. Family units of markedly different size, age, occupation, wealth and tastes must be lumped together and generalizations must be drawn as to spending patterns by income class. Changes in tax base, in the light of these estimated average effects, would operate differently for particular families with similar incomes.

While the exemption of home-consumed food, for example, moves a sales tax generally toward a more progressive distribution of the burden attributable to consumers, the degree of progression actually achieved among taxpayers would differ according to family size and tastes in consumption. And this tendency toward progression, as well as the tendency that the exemption of restaurant food is toward regression, does not hold for many individuals. Considerable food consumed in homes, particularly for entertaining, may be regarded as of a luxury

${ }^{10}$ A number of the difficulties with the type of data used in all the above-mentioned empirical studies of tax burdens are outlined by Hickman, Distribution of the Burden. The data were obtained by a Bureau of Labor Statistics survey for 1950 and compiled in the Wharton School of Finance, Study of Consumer Expenditures, Income and Savings, Philadelphia, 1956. In California, for example, the survey's reported consumption of alcoholic beverages could explain only some 30 per cent of the state tax revenues obtained from these taxed items, and the reported expenditures were accordingly adjusted upward. There were wide disparities for some income classes in reported total incomes and total consumption among local survey areas; adjustments here also seemed advisable. The sample data also indicated that consumer expenditures in California exceeded money income after income taxes in all of the lower seven of the nine income classes employed. 
character, while many lower income persons, especially single ones, find it advisable, if not necessary, to eat out much of the time. Adjustment of tax bases by such exclusions and inclusions may increase progressivity among some taxpayers and regressivity among others.

Professor Hansen's study of sales tax burdens and consumption expenditure patterns emphasized the apparent perversity of horizontal tax differentials as well as differentials between income levels. ${ }^{20} \mathrm{His}$ burden allocations indicate that sales taxes bear more heavily on large families than on small families within every income group. Moreover, families of the same size and the same income were found to bear considerably different sales tax burdens depending upon whether they were rural or urban, upon racial and ethnic characteristics, and simply upon preferences in allocating the same amount of aggregate expenditures among taxable and nontaxable goods and services. Hansen concluded that families of virtually identical characteristics can have substantially different burdens and that there is no apparent way to modify this capriciousness of the sales tax.

As an alternative to the narrowing and adjustment of sales tax bases, tax credits may be employed to offset some of the regressivity of a consumption tax. A per capita credit against tax in effect exempts a given amount of consumption expenditure, gives proportionately greater relief for low incomes, and redresses the heavier burdens that fall on large families at all income levels. It cannot offset the type of differential burdens that Professor Hansen has noted for families of the same size. The sales tax credit can take the form of credits on income tax and direct refunds to individuals not owing income tax who submit refund claims.

If much weight is to be given these types of equity considerations, however, reliance on the individual income tax is preferable. The income tax enables refinements in distribution of burdens (in some views, too many refinements) according to variations in taxpayers' circumstances. If it is the national consensus that large families, elderly people, working wives or incurrers of casualty losses have lesser ability to pay, compensating adjustments can be made in income tax liabilities that would be much more difficult to achieve with indirect taxes.

The adjustment of income tax liabilities through exclusions, deductions and credits alters and obscures the degree of progression indicated by tax rate schedules. If there ever was expectation that vertical equity could be judged by simply comparing individual incomes and progres-

${ }^{20}$ In National Tax Journal, March 1962, p. 13. 
sive rate schedules, that expectation has long since gone by the board. From the start of the federal income tax, distinctions have been permitted between individuals as to sources and uses of income that vitiate easy comparisons between total incomes and tax rates.

To some observers, on the other hand, the income tax in practice has so many shortcomings in spreading tax burdens that it seems desirable to adopt a general sales tax as a supplement. ${ }^{21}$ Persons who avoid or evade "their fair share" of income taxes would at least pay a sales tax and contribute something to government operations.

One facet of this suggestion relates to "loopholes" in the income tax base. Many people believe that some of the existing income tax allowances are unwarranted, even though lists of loopholes may differ. But it is difficult to find a loophole which lacks an economic or equity rationale persuasive to the Congress. One way to improve the tax system is to try to gain agreement that some existing allowances have more disadvantages than advantages and thereby obtain a change in the income tax law. Another is to supplement the income tax with an indirect tax to be borne both by individuals who do and do not continue to have the advantage of the income tax loophole. A general sales tax or value-added tax would have the advantage of a fresh start, but one may wonder whether the new tax might not also be somewhat less than uniform in application and have its own loopholes. Many state sales taxes, for example, have dealt very tenderly with farmers. In view of the traditions in the United States, it might also be likely that under a "general" value-added tax some special allowance might be made for the value added attributable to discoverers of oil wells or the recipients of coal and iron ore royalties.

The other facet of the suggestion relates to evasion. Income taxes are to some extent subject to evasion, although the opportunities seem to be narrowing with the introduction of account numbers for taxpayers and continuing improvements in record keeping and information reporting. Sales taxes and value-added taxes are also subject to evasion, and some persons, whose circumstances permit income tax evasion, are also in relatively strategic positions to shade their liabilities under indirect taxes, if they are inclined to cheat.

Opinions may differ as to whether income tax inequities resulting from avoidance and evasion are so bad, and are so unyielding to direct correction, that recourse to indirect taxes would be warranted as a partial remedy. Attempts at direct improvement of income taxes involve frus-

${ }^{21}$ Cf. Somers, in Proceedings of the National Tax Association for 1961, p. 615. 
trations for tax reformers. But reformers' feelings of frustration are not likely to be entirely eliminated as they watch Congress shape a general sales or value-added tax.

\section{ALTERNATIVE CRITERIA FOR JUDGING EQUITABLE DISTRIBUTION}

The exempting of savings or capital accumulation through retail sales or consumption value-added taxes poses the old question of what is fundamentally the better basis for judging the equitable distribution of taxes-income in the sense of accretions to economic position or income in the sense of consumption. There are reasonable arguments for either of the basic standards, and a choice between them rests on a weighing of value judgments. If one takes the view that the benefit of income is in consumption, whether current or deferred, and savings represent sacrifice of present consumption in order to enjoy more later, the equating of taxable capacity with consumption has much appeal. ${ }^{22}$ If one believes that receipts devoted to saving and acquisition of assets also bring current benefits in power, prestige, and security that are as advantageous as income devoted to current consumption, the accretion concept of taxable income seems superior. ${ }^{23}$

In a general way, the choice is between comparative systems: one which exempts savings and investment, which consumes less currently with the expectation of larger total future income that in some degree will benefit all citizens, and which tolerates growing disparities in wealth among individuals; and a second which taxes savings and investment relatively heavily, restrains disparities in privately accumulated wealth, and tolerates a somewhat lower rate of growth than might otherwise be achieved. ${ }^{24}$

The use of "Fisher income" or consumption as the denominator and sales taxes as the numerator in ratios of relative burden distribution, as Davies suggests, ${ }^{25}$ will of course avoid the regressivity that appears when current income is used as the denominator. This is acceptable for those who believe equitable tax distributions should be judged by ratios of tax to consumption, but for those who are concerned with burdens

22 See David G. Davies' discussion of "Fisher income" or "corrected disposable receipts" in his several articles, cited above, and Kaldor's thorough discussion of income concepts in his An Expenditure Tax, Appendix to Chapter I and Chapter II.

${ }^{23}$ Cf. Rolph, Theory of Fiscal Economics, pp. 263-264, and Kaldor, An Expenditure Tax, p. 88.

${ }^{24}$ Henry C. Simons, Personal Income Taxation, pp. 22, 25.

${ }_{25}$ "Commodity Taxation and Equity," Journal of Finance, December 1961, pp. 584-585, and 590; "Progressiveness of a Sales Tax in Relation to Various Income Tax Bases," American Economic Review, December 1960, pp. 992-994. 
relative to income including accretion, introduction of the Fisher income concept simply begs the question.

In employing the broader income standard, however, the shortcomings of comparative tax and income data on an annual basis should be taken into account, since they make consumption taxes look more regressive than they are on the average. For many individuals, patterns of income and consumption expenditures do not run parallel over time. In some years consumption exceeds income and in others the reverse is true. Probably for the average individual there is borrowing or dissaving in early years of education and family formation, saving in middle years when house mortgages are amortized and pension rights acquired, and then dissaving upon retirement. For most persons, savings will occur in higher income years, dissaving in lower income years. A person who had such a pattern of income and expenditure, but who left at his death no net accumulation of savings, might pay the same aggregate of taxes over his lifetime under either a proportional income tax or an equal yield flat-rate tax on consumption. But a comparison of his consumption tax with his income year by year would indicate that this tax was regressive. A similar exaggeration of regression arises from surveys of different individuals' income, consumption, and estimated sales tax burdens in any one year. These surveys reflect consistent average dissaving in the lowest income classes, which may be at least partially explained on the grounds that many persons are only temporarily in these classes and are consuming and paying sales taxes on the basis of income obtained or to be obtained in other years.

In endeavoring to judge the equity of consumption tax distributions with respect to individuals' incomes, annual tax and income figures leave much to be desired. Similar problems are encountered in assessing the fairness of relative burdens under a progressive income tax between persons with varying and stable incomes. Ideally, comparisons might be made between lifetime taxes and incomes. ${ }^{26}$

In the absence of lifetime sales tax and income data, it has been suggested that relative consumption tax burdens might well be analyzed in relation to "permanent income." 27 If, as Professor Friedman has hypothesized, ${ }^{28}$ people consume not on the basis of their current income but according to what they believe is their permanent income, then they

\footnotetext{
${ }^{26}$ Cf. William Vickrey, Agenda for Progressive Taxation, New York, 1947, pp. 172-197.

${ }^{27}$ David G. Davies, "Commodity Taxation and Equity," pp. 584-585 and 590.

${ }^{28}$ Milton Friedman, $A$ Theory of the Consumption Function, Princeton for NBER, 1957.
} 
might also prefer to judge their tax burdens in relation to permanent income. Some of the apparent regressiveness of sales taxes, when persons are in some years dissavers and in other years savers, would be ironed out. Practically, however, the theoretical construct of what people believe their average income will be over a period of years seems to have little value as a basis for judging how regressive or progressive a sales tax system is, or how it might be altered to achieve a shading of regression. As Professor Friedman has indicated, the permanent income concept involves several subjective variables. Permanent income is not expected lifetime earnings; it varies with the age of the individual, his horizon and foresightedness. An individual's concept of the permanent components of income and consumption for his own time horizons can never be observed directly; "we can only observe ex post what it [the consumer unit] spends and what it receives." ${ }^{29}$ While these theoretical constructs provide insight to economists in trying to understand consumer behavior, they would seem of very limited help to a legislative committee trying to adjust tax burdens equitably with respect to individuals' actual consumption and income.

To assist in judging the weight of sales tax burdens in relation to income, further empirical studies of consumption and income patterns over several years would be instructive. Meanwhile, conclusions about the degree and import of regressivity based on one-year comparisons of taxes attributed to groups of consumers and their current incomes should be regarded as tentative. Some allowance might well be made for the larger fluctuations in incomes than in consumption over time. The penchant of burden distribution studies to attribute all indirect taxes to consumers may also accentuate the indicated regressivity.

So far as savings are short run and used for consumption within a few years, individuals might be taxed approximately equally over the years by either a proportional income tax or a general consumption tax. But a consumption tax would give a different distribution of tax payments than the income tax over a lifetime that included equal aggregate amounts of saving and dissaving. Is an individual treated more fairly if his tax burden is geared to his consumption or to his current income? There seems to be a common and reasonable view that persons should be taxed more when they have larger incomes rather than place heavier burdens on them in periods of retirement, dissaving, or net borrowing. The fact that during a year some persons consume but pay no current

${ }^{29}$ Ibid., pp. 93, 221-222. 
tax does not necessarily create an injustice if the income from which the savings have been, or will be, accumulated is subject to tax. ${ }^{30}$

Where there are net savings and accumulation from generation to generation, the choice of consumption, rather than income including accretion, as a standard of equity will give quite different results in burden distribution and especially if reliance is placed on indirect taxes. Accumulations that are not dissaved but parlayed remain untaxed under the consumption basis, and the opportunities for this seem to increase more than proportionately with very large incomes. It can be argued that taxes directed to consumption may achieve a progressive distribution of burden among individuals - not only with respect to consumption but also generally and roughly with respect to incomes-providing direct personal consumption or spending taxes are employed. But proposals to tax according to consumption through general indirect levies refiect a willingness to forego progression and to accept a considerable degree of regression relative to individual incomes. Broad levies on firms producing consumption items are typically at flat rates. Higher rates may be imposed on producers of so-called luxuries, but there is uncertainty about the extent the rate differentials may be attributed to producers or consumers of the items, and for taxes on items yielding substantial revenues there is doubt that consumption varies in significant progression with individual income levels. In any event, the consumption bases exclude the net accumulations of savings which tend to rise progressively with income levels.

\section{CONCLUSION}

Equity in the distribution of burdens is only one of several considerations in evaluating tax policies. It remains a fairly important objective in current thinking and probably receives more attention from legislative bodies than some other long-standing objectives, such as tax simplicity.

Perhaps too much attention is paid to equity and too much effort devoted to identification of ultimate tax burdens. It is often said that

${ }^{30}$ The notion that equity is reasonably maintained if untaxed consumption comes out of previously taxed income is difficult to accept if different generations are involved. The unproductive playboy consuming inherited wealth seems to come off too lightly even if the prior savings were taxed, but there is a question of how much weight should be given him as a determining factor in a choice of tax systems. In the United States, the volume of consumption by wastrels of grandfathers' fortunes is probably slight compared to dissaving by persons who do their own accumulating. The relative effects on these latter persons of the consumption tax pattern must be weighed, as well as the fact that the consumption tax exempts net accumulations between generations. 
only individuals really pay taxes and accordingly all taxes must be allocated to somebody. In the same broad sense it might be said that ultimately only individuals receive income. For purposes other than taxation there seems to be less concern about the need or merit of trying to attribute to individuals all shares of income retained by corporations, mutual financial institutions, trusts, unvested pension funds, churches, universities, and the like. One might likewise take the pragmatic position that taxes are taken by the government out of various income streams and the more important effects are those on national income, price levels, consumption, investment, and the balance of international payments, rather than burden distributions among individuals. This is perhaps the case for countries that must rely heavily on import duties.

To the extent that we are concerned about equitable distribution of taxes among individuals in the United States, it is difficult to see how the objective of equity would be better served by a federal government shift from direct to indirect taxes. Individual income taxes may be allocated with relative precision, and a link between government expenditures and individual burdens is fairly clear. The corporation income tax now burdens equity shareholders and consumers in only vaguely understood proportions, but a substitution of a corporate value-added tax or a sales tax is not likely to increase understanding of final burden distributions among individuals.

Unless one despairs of the country's ability to reform the income taxes in line with changing needs, there would seem little reason on equity grounds to move toward more, rather than less, federal reliance on indirect taxes. If there is general agreement on the broad lines reform of the federal tax system should take, the income taxes are presumably adaptable. The existing unneutrality of the corporate tax against equity investment could be approximately eliminated by changing the tax to one designed to integrate tax treatment at the corporate and individual levels, without the need for a new set of business taxes that would bring their own problems of integration with individual taxes. Adjustment of income tax bases and rate schedules could make burdens conform to more desirable degrees of progressivity or proportionality. And if it appeared advisable on economic grounds to exclude savings and investment from tax, this too could be accomplished under the income tax, with probably a clearer general understanding of what was sought and achieved than under indirect taxes. 


\section{Administration and Compliance ${ }^{31}$}

The federal government can levy either broad-based income taxes or indirect taxes to raise substantial revenues without prohibitive costs of administration and compliance. Generalizations about relative enforcement burdens are difficult. They must depend upon the particular type of tax employed, the efforts made to secure compliance, and the revenue yields, since there are significant economies of scale. No conclusive evidence now indicates that one broad-based form of tax need involve much larger aggregate administrative and compliance costs than the other.

Variations in administrative costs among types of income taxes or types of indirect taxes may well be wider than between an income tax and a sales tax, each of which were designed for ease of collection and payment. If we were content with rough tax justice and gave high priority to simplicity, a personal income tax could be based on a relatively simple concept of adjusted gross income, and collected largely through withholding and uncomplicated tax returns. If we insist on varying treatment for different sources of income, including several classes of genuine and pseudo capital gains, different capital investment allowances or incentives, or different medical expense deductions depending upon marital status and age of taxpayer or dependent, then rules and procedures are complicated. Sales taxes are not immune from similar complexities. The Canadians note, for example, that the adoption of their manufacturers sales tax forty years ago "appeared to offer hope of simplicity ... now it takes more than 200 pages of printing simply to describe the exemptions." ${ }_{2}$

In fiscal 1963, the U.S. Internal Revenue Service spent $\$ 501$ million and collected $\$ 106$ billion of revenues. ${ }^{33}$ The average cost of collecting $\$ 100$ was $\$ 0.47$. Since income taxes were about four-fifths of total collections, the cost ratio is an approximation of government costs of administering large-scale income taxes. Professor Due has found that costs

${ }^{31}$ The author wishes to acknowledge helpful suggestions of Robert B. Bangs, Charles F. Conlon and John Copeland on administrative problems, and heavy indebtedness to the writings of Professor Due on sales tax administration in the United States, Canada, and elsewhere.

32 "Fact and Opinion," Canadian Tax Journal, July-August 1962, p. 226. In discussing what is and what is not taxable under the Canadian law, $\mathrm{H}$. O. Spindler states: "The safe assumption where sales taxes are involved is that few people are well informed. Even well known contractors often give the impression that they have not sorted out the mysteries of sales tax." "Corporate Sales Tax Pitfalls," Corporate Management Conference, Montreal 1963, Canadian Tax Foundation, p. 10.

${ }^{33}$ Internal Revenue Service, Reports Division, Internal Revenue Service-Cost, Tax Collections, Employees, and the U.S. Population Since 1866, Document No. 5227 (10-63). 
of state sales tax administration range from .63 to 1.9 per cent of receipts, ${ }^{34}$ and he suggests in his introductory paper that effective collection of a 3 per cent federal sales tax would cost roughly 1.75 per cent, and at a 10 per cent tax rate, perhaps .7 per cent. Generalizations from over-all ratios must be qualified. The ratios change drastically with changes in tax bases and rates. The Internal Revenue Service ratio of costs to collections fell from $\$ 1.12$ per $\$ 100$ in 1939 to $\$ 0.33$ in 1945 ; costs more than doubled, but revenues rose much more rapidly with higher rates and lowering of individual income tax exemptions. State sales tax costs have fallen, relative to revenue, as rates have risen.

Meaningful comparison of cost ratios should relate to equally effective tax collection efforts, but these are difficult to judge. Differences in cost ratios among sales tax states often appear to reflect differences in effort rather than efficiency. Data collected by the National Association of Tax Administrators from sales tax states indicate that the proportion of registered businesses audited varies widely. A few states audit 10 per cent or more of active accounts, most audit about 3 per cent or less, and a few leave collection largely to voluntary compliance, auditing 1 in 150 or 200 of active accounts. ${ }^{35}$ The thoroughness of audits may also differ markedly. On the other hand, continuing questions are raised about the adequacy of enforcement effort at the federal level. In fiscal 1962 only 5 per cent of individual and 10 per cent of corporation income tax returns were audited, and field examinations were made in less than one-quarter of the cases audited ${ }^{36}$ Perennial presentations to appropriation committees show that for additional dollars devoted to federal income tax administration, direct enforcement revenues could be increased by about a 6 to 1 ratio; in addition, improvements in voluntary compliance might be expected. ${ }^{37}$

The citizens' representatives in Congress and in state legislatures appear to reflect a general preference for stopping well short of equating marginal cost and direct marginal revenue in the area of tax administra-

${ }^{34}$ State Sales Tax Administration, Chicago, 1963, p. 226.

36 "Supplementary Statement of the National Association of Tax Administrators," U.S. House of Representatives, Committee on the Judiciary, Hearings of Special Subcommittee on State Taxation of Interstate Commerce, 88th Cong., 1st Sess. (1963).

${ }^{36}$ 100th Annual Report of the Commissioner of Internal Revenue, 1962, Washington, p. 33.

${ }^{37}$ See, for example, the statement of the Commissioner of Internal Revenue in U.S. Congress, Senate, Treasury-Post Office Departments and Executive Office Appropriations for 1963, hearing before the Subcommittee of the Committee on Appropriations, 87th Cong. 2nd Sess. (1962), pp. 40-52. 
tion. Accordingly, comparability of enforcement effort for different taxes is uncertain.

Less is known about comparative costs of tax compliance. The Canadian Tax Foundation in 1960 understook a path-breaking study in this area through questionnaires completed by 125 companies among their membership. ${ }^{38}$ This was not a representative sample that would permit generalizations and the results in many ways seem inconclusive. It was clear that even partially accounted for compliance costs were substantial, and the study serves to indicate problems to be dealt with in further efforts to measure compliance burdens. For comparative purposes several yardsticks may be used: compliance costs may be related to (a) taxes remitted to the government, (b) net sales, (c) total operating expenses, (d) assets, or (e) number of employees (the number of employees engaged in tax work may be compared with total employees). For different types of businesses and different taxes, each proposed yardstick has shortcomings. For example, the most common comparison of costs to tax remitted has limitations for corporate net income taxes where some companies break even or have losses. There are disparities in what different companies treat as tax collection costs. ${ }^{39}$ And for those that maintain separate tax departments, the allocation of costs to different taxes must be estimated. The respondents apparently dealt only with office costs, and did not consider the broader costs of retail sales taxes involved in compliance of sales clerks.

The survey indicated that the costs of collecting taxes for which the company is itself liable-corporation income tax, property tax, and business taxes-averaged .75 per cent of the taxes paid, but the range of ratios stretched from .04 to 4.76 per cent. On taxes for which the companies act as a collection agent for governments, the reported costs averaged just over .5 per cent of remittances, but the range in ratios ran from .04 to 9.16 per cent. The work attributed to payroll withholding accounted for about half the total reported costs of serving as collection agents. Data on collection costs for provincial and municipal

${ }^{88}$ Marion H. Bryden, The Costs of Tax Compliance, Canadian Tax Papers, No. 25, Toronto, 1961.

${ }^{30}$ One respondent commented: "We operate five wholesale and five retail outlets and no one is directly responsible for tax matters except corporation income taxes. All other handling of tax matters is incidental to the recording of transactions and responsibility is so widely spread as to be impractical of cost determination. Even corporation tax is only a matter of preparation of the return as a direct operation after all information has been recorded and analyzed in the course of audit and preparation of financial statements. At the outside a day of my time (the secretarytreasurer) is required for this and typing represents an hour's time." Ibid., p. 5. 
retail sales taxes were particularly unsatisfactory; only 65 companies reported. They were asked to report only costs in excess of commissions they were allowed by the governments as collection agents; and there was confusion among respondents in reporting sales taxes attributable to their customers and to themselves as consumers of final products. The study concluded that "The most significant observation that can be drawn from the replies is that companies vary widely in their tax work costs. This is not only true of companies in different industries but is also evident within the same industry." 40

Any precise conclusions about comparative administration and compliance costs of "equally effective" income and general sales taxes will require the development of more adequate data than are now available.

\section{A CONSUMPTION TAX BASE}

A movement for the United States government to rely more heavily on indirect taxes could take any of several forms and could differ with the emphasis given to objectives of broad economic neutrality, equity among individuals, or ease of administration. The following discussion seeks merely to indicate some of the enforcement and compliance problems that might be expected if indirect taxation were undertaken in alternative ways.

In considering alternative taxes, it is common to discuss abstractly a general retail sales tax on all consumption. An interesting gambit with respect to retail sales taxes is to consider the base of a tax on final consumption items that might be acceptable for federal use. Opinions will differ as to what should or should not be included. A list of tentative suggestions serves to indicate some of the basic issues and administrative and compliance problems that would arise.

The objective of economic neutrality argues for a broad and uniform base, so that there would be a minimum of tax-induced change in consumers' expenditures, and a minimum of distorting effects among producers of taxed and nontaxed items. This means that, in contrast to many existing sales taxes, an effort should be made to include services as well as tangible goods. Services comprised 41.3 per cent of personal consumption expenditures in the United States in 1962, as compared to 37.1 per cent in 1949 and 36.4 per cent in $1939 .{ }^{41}$

Considerations of equity and social policy suggest, on the other hand,

${ }^{40}$ Ibid., p. 31.

${ }^{41}$ Economic Report of the President, January 1963, Table C-2, p. 172. 
that an acceptable consumption tax base for the federal government would probably be narrowed to eliminate the more regressive effects upon consumers, as well as adverse effects upon the consumption of socially desirable items. Departures from uniformity through exemptions create problems of definition and record keeping that complicate administration and compliance.

It is here assumed that to be worthwhile a general federal consumption tax should raise substantial revenues, i.e., enough to replace most of the selective excises and to contribute significantly to a replacement of some existing individual income taxes and/or corporate income taxes. It might be assumed that existing federal excises on gasoline, tobacco, and alcoholic beverages would be maintained, since these have widely accepted justifications on benefit or sumptuary grounds. But the new general tax would not be imposed on these items, since they are now heavily taxed by both state and federal governments. ${ }^{42}$ Elimination of the other excises would reduce revenues by $\$ 4.3$ billion (fiscal year 1963).

What would a general sales tax yield for each 1 per cent of tax rate? Some rough approximations may be made from Table 1 which is reproduced from the Department of Commerce, Survey of Current Business. In the national income accounts, total personal consumption expenditures were $\$ 355.4$ billion in 1962 . If all of this were taxable at 3 per cent, revenues of $\$ 10.7$ billion might be raised. But the total of consumption expenditures is considerably larger than any probable tax base. ${ }^{43}$ Exclusion of gasoline, tobacco, alcoholic beverages, and state and local road tolls would remove $\$ 30.9$ billion from the base. It seems improbable that a tax would apply to consumer outlays for foreign travel, religious and welfare activities, private education and research, a total of $\$ 13.7$ billion.

There are social policy justifications for not applying a substantial federal tax to outlays for medical care and death expenses. Illness and expensive drugs reduce ability to pay taxes. Accordingly, $\$ 23.7$ billion might be excluded from a sales tax base. Exemption of drugs is troublesome under a consumption tax as under an income tax, since it is difficult to draw the line between drugs and household remedies, cough drops, dentrifrices, and suntan lotions. Limiting exemption to a prescription basis is a simplifying device but omits some commonly sold

\footnotetext{
${ }^{42}$ Alternatively the general tax could apply to these commodities and the specific excise rates reduced to avoid extremely heavy total taxes on the products, but the effect on aggregate revenues would be about the same.

${ }^{43}$ In considering potential yields, the possible taxation of government purchases is ignored since additional sales tax revenues would be offset by additional costs to governments and the need for further revenues.
} 
TABLE 1

PERSONAL CONSUMPTION EXPENUITURES, BY TYPE OF PRODUCT ${ }^{\mathrm{a}}, 1962$ (million dollars)

I. Food ${ }^{b}$ and tobacco

91,974

1. Food purchased for off-premise consumption (n.d.c.)

63,633

2. Purchased meals and beverages (n.d.c.)

3. Food furnished government (including military) and commercial employees (n.d.c.)

18,236

4. Food produced and consumed on farms (n.d.c.)

1,347

5. Tobacco products (n.d.c.)

1,004

7,754

II. clothing, accessories, and jewelry

1. Shoes and other footwear (n.d.c.)

2. Shoe cleaning and repair (s.)

35,759

4,703

280

3. Clothing and accessories except footwear 24,983

a. Women's and children's (n.d.c.)

b. Men's and boys' (n.d.c.)

15,857

9,126

4. Standard clothing issued to military personnel (n.d.c.)

5. Cleaning, dyeing, pressing, alteration, storage, and repair of garments including furs (in shops) not elsewhere classified (s.)

6. Laundering in establishments (s.)

7. Jewelry and watches (d.c.)

8. Uther (s.)

III. Personal care

1. Toilet articles and preparations (n.d.c.)

2. Barbershops, beauty parlors, and baths (s.)

2,101

898

2,160

566

6,213

3,323

2,890

IV. Housing

46,595

1. Owner-occupied nonf arm dwellings--spacerental value (s.)

30,193

2. Tenant-occupied nonfarm dwellings (including lodging houses)--space rent (s.)

3. Rental value of farmhouses (s.)

12,914

2,064

4. Other (s.)

1,424

V. Household operation

49,638

1. Furniture, including mattresses and bedsprings (d.c.)

5,054

4,845

3. China, glassware, tableware, and utensils (d, c. )

2,316

3,977

4. Other durable house furnishings (d.c.)

3,352

6. Cleaning and polishing preparations, and miscellaneous household supplies and paper products (n.d.c.)

7. Stationery and writing supplies (n.d.c.)

a. Electricity (s.)

3,552

b. Gas (s.)

1,338

d. Other fuel and ice (n.d.c.)

3,715

(continued) 
TABLE 1 (continued)

\begin{tabular}{|c|c|c|}
\hline & $\begin{array}{l}\text { 9. Telephone, telegraph, cable, and wireless (s.) } \\
\text { 10. Domestic service (s.) } \\
\text { 11. Other (s.) }\end{array}$ & $\begin{array}{l}4,989 \\
3,838 \\
2,374\end{array}$ \\
\hline VI. & $\begin{array}{l}\text { Medical care and death expenses } \\
\text { 1. Drug preparations and sundries (n.d.c.) } \\
\text { 2. Ophthalmic products and orthopedic appliances } \\
\text { (d.c.) } \\
\text { 3. Physicians (s.) } \\
\text { 4. Dentists (s.) } \\
\text { 5. Uther professional services (s.) } \\
\text { 6. Privately controlled hospitals and sanitariums } \\
\text { (s,) } \\
\text { 7. Medical care and hospitalization insurance (s.) } \\
\text { 8. Funeral and burial expenses (s.) }\end{array}$ & $\begin{array}{r}1,372 \\
5,298 \\
2,189 \\
y 75\end{array}$ \\
\hline VII. & $\begin{array}{l}\text { Personal business } \\
\text { 1. Brokerage charges and interest, and investment } \\
\text { counseling (s.) } \\
\text { 2. Bank service charges, trust services, and } \\
\text { safe-deposit box rental (s.) } \\
\text { 3. Services furnished without payment by financial } \\
\text { intermediaries except insurance companies (s.) } \\
\text { 4. Expense of handling life insurance (s.) } \\
\text { 5. Legal services (s.) } \\
\text { 6. Interest on personal debt (s.) } \\
\text { 7. Other (s.) }\end{array}$ & $\begin{array}{l}5,124 \\
4,834 \\
2,082 \\
6,950 \\
1,095\end{array}$ \\
\hline VIII. & $\begin{array}{l}\text { Transportation } \\
\text { 1. User-operated transportation } \\
\text { a, New cars and net purchases of used cars } \\
\text { (d.c.) } \\
\text { b. Tires, tubes, accessories, and parts (d.c.) } \\
\text { c. Automobile repair, greasing, washing, } \\
\text { parking, storage, and rental (s.) } \\
\text { d. Gasoline and oil (n.d.c.) } \\
\text { e. Bridge, tunnel, ferry, and road tolls (s.) } \\
\text { f. Autoniobile insurance premiums less claims } \\
\text { paid (s.) } \\
\text { 2urchased local transportation } \\
\text { a. Street and electric railway and local bus } \\
\text { (s.) } \\
\text { b. Taxicab (s.) } \\
\text { c. Kailway (commutation) (s.) } \\
\text { 3. Purchased lntercity transportation } \\
\text { a. Railway (excluding commutation) and sleeping } \\
\text { and parlor car (s.) } \\
\text { b. Intercity bus (s.) } \\
\text { c. Airline (s.) } \\
\text { d. Other (s.) }\end{array}$ & $\begin{array}{r}44,082 \\
40,389 \\
17,347 \\
3,101 \\
5,282 \\
12,285 \\
309 \\
2,065 \\
1,989 \\
1,243 \\
621 \\
125 \\
1,704 \\
320 \\
337 \\
1,024 \\
23\end{array}$ \\
\hline IX. & $\begin{array}{l}\text { Recreation } \\
\text { 1. Books and maps (d.c.) } \\
\text { 2. Magazines, newspapers, and sheet muslc (n.d.c.) } \\
\text { 3. Nondurable toys and sport supplies (n.d.c.) }\end{array}$ & $\begin{array}{r}21,555 \\
1,677 \\
2,645 \\
2,786\end{array}$ \\
\hline
\end{tabular}

(continued) 
TABLE 1 (concluded)

\begin{tabular}{|c|c|}
\hline $\begin{array}{l}\text { 4. Wheel goods, durable toys, sport equipment, } \\
\text { boats, and pleasure aircraft (d.c.) } \\
\text { 5. Radio and television receivers, records, } \\
\text { and musical instruments (d.c.) } \\
\text { 6. Kadio and television repair (s.) } \\
\text { 7. Flowers, seeds, and potted plants (n.d.c.) } \\
\text { 8. Admissions to specified spectator amusements } \\
\text { a. Motion picture theaters (s.) } \\
\text { b. Legitimate theaters and opera, and } \\
\text { entertainments of nonprofit institutions } \\
\text { (except athletics) (s.) } \\
\text { c. Spectator sports (s.) } \\
\text { 9. Clubs and fraternal organizations except } \\
\text { insurance (s.) } \\
\text { 10. Commercial participant amusements (s.) } \\
\text { 11. Pari-mutuel net receipts (s.) } \\
\text { 12. Other (s.) }\end{array}$ & $\begin{array}{r}2,386 \\
4,001 \\
950 \\
1,086 \\
2,123 \\
1,405\end{array}$ \\
\hline $\begin{array}{l}\text { X. Private education and research } \\
\text { 1. Higher education (s.) } \\
\text { 2. Elementary and secondary schools (s.) } \\
\text { 3. Other (s.) }\end{array}$ & $\begin{array}{r}5,208 \\
2,461 \\
1,832 \\
915\end{array}$ \\
\hline XI. Religlous and welfare activities (s.) & 5,140 \\
\hline $\begin{array}{l}\text { XII. Foreign travel and remittances--net } \\
\text { 1. Foreign travel by United States residents (s.) } \\
\text { 2. Expenditures abroad by United States Govern- } \\
\text { ment personnel (military and civilian) } \\
\text { (n.d.c.) } \\
\text { 3. Personal cash remittances to foreign } \\
\text { countries less personal cash remittances } \\
\text { to the United States by foreigners (s.) } \\
\text { 4. Less: expenditures in the United States by } \\
\text { foreigners (s.) }\end{array}$ & $\begin{array}{l}3,377 \\
2,555 \\
1,483\end{array}$ \\
\hline Total personal consumption expenditures & 355,360 \\
\hline Durable commodities (d.c.) & 48,236 \\
\hline Nondurable commodities (n.d.c.) & 161,406 \\
\hline Services (6.) & 145,718 \\
\hline
\end{tabular}

Source: U.S. Department of Commerce, Survey of Current Business, July 1963, p. 20.

${ }^{a}$ Consumer durable commodities are designated (d,c.), nondurable commodities (n.d.c.), and services (s.) following group titles.

${ }^{b}$ Expenditures for food (items 1-4) include consumer expenditures for alcoholic beverages of $\$ 10,665$ million. Expenditures for food (items 1-4) excluding alcoholic beverages are $\$ 73,555$ million. 
drugs such as insulin and cortisone that are needed by persons with serious illnesses. Exempting items beyond prescription drugs complicates administration since some of these items are sold by supermarkets, variety stores and others. Exemption of the services of doctors, dentists and morticians raises problems with respect to comparative tax coverage of other professional services. However, it seems probable that the Congress would exempt expenditures approximating $\$ 23.7$ billion in this area.

Food exemption is the principal factor in removing the regressive effect of general sales taxes upon consumers. And there would seem to be little point in trying to tax the national income categories of food produced and consumed on farms, or that furnished government employees, including the military. If only food purchased in restaurants were taxable, the personal consumption tax base would be reduced by $\$ 58.3$ billion. Food exemptions raise many administrative problems; separating taxable from nontaxable items is troublesome for both taxpayers and tax auditors. Retailers who sell food usually sell nonfood items such as paper goods, housecleaning supplies and the like. These problems have been dealt with in various ways under state sales taxes, including full taxation of food, exemption of food but not meals, exemption of restaurant meals under 51\& in Pennsylvania and $\$ 1$ in Connecticut, and the allowance of a per capita credit under the sales tax to compensate for the regressive effect of including food. ${ }^{44}$ One may surmise that a federal tax would probably exempt at least food for home consumption or include a credit that would reduce tax yield an equivalent amount.

The consumption of housing cannot be taxed readily and equitably under an indirect tax. The bulk of housing services consumed in the United States is from owner-occupied dwellings, and payments for this do not pass through business firms on which an indirect tax could be levied. The Congress has not yet seriously considered taxing the imputed rent of home owners under the income tax, and it may be doubted that a general sales tax would be supplemented by a direct levy on the

${ }^{44}$ Indiana's 2 per cent sales tax, enacted in 1963, allowed a credit of $\$ 6$ per capita to compensate for the inclusion of food within the tax base. A similar proposal was made in Wisconsin, but a bill for a sales tax incorporating the credit was vetoed. In order to eliminate regressivity and discrimination among families, a Wisconsin committee recommended in preference to a food exemption a $\$ 15$ per capita credit for a 3 per cent sales tax, to be implemented through credits against state income tax and direct refunds for those not liable for income tax. University of Wisconsin Tax Study Committee, Wisconsin's State and Local Tax Burden, Madison, 1959, pp. 86-92, and 147 . 
rental value of farmhouses or urban dwellings. An indirect tax could be imposed on firms that collect rents from individuals, but this procedure would seem far from satisfactory. The income tax bias against renters and in favor of home owners would be aggravated by a sales tax bias. A considerable part of rent paid, including that in lodging houses, does not go through established business firms, but passes among individuals to whom application of sales tax collection procedures would be difficult. To apply the sales tax only through rental firms of some given size creates discrimination among renters. A sales tax could be applied to new construction and the sale of homes. Presumably such a tax should cover the value of land as well as improvements, for over the life of residential property a good deal of the consumption services enjoyed reflect the use of the site. This approach, however, would prejudice the current purchaser of housing assets and fail to reach the consumption value of homes that are not transferred. It may also be recognized that consumers' outlays for shelter, a basic amenity of life, are, and will continue to be, taxed rather heavily, and in some cases regressively, under local property taxes. For these several reasons, most if not all of the $\$ 46.6$ billion of consumption expenditures for housing could not, or probably would not, be includable in a sales tax base.

Studies of state sales tax bases have shown that inclusion of utilitieswater, gas, electricity, and transportation-tends to increase regressiveness. ${ }^{45}$ Many states exempt them, New Mexico taxes all of them, and other states have varying applicability of general or special taxes to these services. Professor Due suggests that sales taxation of utilities be confined to telephone and telegraph services, electricity, and gas. Hickman's findings and the action of many states indicate that a persuasive case may also be made for excluding electricity and gas. If avoidance of regressivity and social policy to foster public transportation were given considerable weight in the shaping of a federal sales tax base, probably $\$ 1.5$ or $\$ 16$ billion of consumer expenditures for household and transportation utilities would not be included.

Domestic services of $\$ 3.8$ billion would be exceedingly difficult to include within a consumption tax base; it would seem inappropriate and probably ineffectual to require either housewives or maids to file sales tax returns with the federal government on payments for services.

It would be anomalous to apply a sales tax to the $\$ 7$ billion of interest paid on personal debt. It may also be questioned whether a sales tax

${ }^{45} \mathrm{Cf}$. William H. Hickman, Distribution of the Burden, pp. 14, 22. John F. Due, State Sales Tax Administration, Chapter VII. 
should apply to legal services or the handling of life insurance, especially if medical and dental services were excluded. On this question Due's conclusion after surveying state sales taxes is of interest:

The type of service most suitable for inclusion within the tax is that rendered by business establishments, rather than individuals or professional men. If the tax is confined to this group, overall administration will be simplified; if it is extended to personal service rendered by individuals and professional men, a number of new problems are created. Furthermore, there are significant objections as a matter of social policy to taxing medical, dental, hospital and related services, legal services, and the like. Other services, such as accounting, are rendered primarily to business firms, and should not be taxed, for the same reasons which apply to all other producers goods. ${ }^{46}$

This list of probable exclusions reflects no more compassion for the taxpayer, and particularly the low income level taxpayer, than is usually evinced by the tax committees of the Congress. This tentative list indicates exclusion of about $\$ 215$ billion from the total of $\$ 355.4$ billion personal consumption expenditures in reaching a federal sales tax base of about 40 per cent of total consumption, or $\$ 140$ billion at 1962 levels. ${ }^{47}$ A 10 per cent federal sales tax on this base would yield approximately $\$ 14$ billion, $\$ 4.3$ billion of which might be used to replace excises other than on tobacco, alcoholic beverages and motor fuel, leaving about $\$ 9.7$ billion for replacement of individual and/or corporate income tax receipts. To replace the entire corporation income tax yield of $\$ 21.6$ billion for fiscal 1963, as well as the indicated selective excises, would have required an 18.5 per cent federal retail sales tax on this base.

A tax base of 40 per cent of consumers expenditures would fall far short of some economists' ideal of a general and neutral tax system. A 10 per cent tax on some uses of funds but not on others would have significant substitution effects. If the regressive character of the sales tax were to be overlooked and food, all utilities, medical care, death expenses, and some other items were included in the base, the coverage could be run up to perhaps 70 per cent of consumer expenditures, but would still be incomplete. Whether, on the other hand, the exclusions tentatively suggested would make the system conform to other economists' ideal of a proportional or progressive sales tax system would be

${ }^{46}$ Ibid., Chapter VIII.

${ }^{47}$ Cf. William Fellner, "Possibilities of Broadening the Tax Base, Reducing Tax Rates, and Promoting Economic Growth," Tax Revision Compendium, p. 195. Professor Fellner, while declining to try to spell out a specific list of items, suggested that a federal retail sales tax might appropriately apply to about 40 per cent of current national consumption. 
difficult to say. In any case, the endeavor to design a base of final consumption items would involve serious but apparently not insurmountable problems for legislative draftsmen, administrators, and taxpayers in the distinguishing of taxable and nontaxable transactions.

\section{A BASE INCLUdiNg FINAL USE OF PRODUCERS GOODS}

The suggested sales tax base of final consumption items would cover many services, such as for personal care, cleaning, and repairs, not typically taxed by most states. But the base would be smaller in other respects than the typical state retail sales tax base, since the state taxes usually apply to some purchases by producers and are to this extent multiple stage taxes. If a federal levy were oriented not simply toward consumer expenditures but more practicably toward the type of sales tax base that has developed among the states, additional revenue and additional problems might be contemplated.

The states in varying degrees have necessarily sought revenues where they may be obtained with relative ease from larger firms, rather than rigorously following principles of economic neutrality and uniform application of the tax only at the retail level. Sales of producers goods by manufacturers and wholesalers have been estimated by Professor Due to account for 10 to 20 per cent of state "retail" sales tax yields, the range depending mainly on whether or not industrial equipment is exempt and on the tax status of food. ${ }^{48}$ These figures appear to understate the proportion of all taxable sales made to business as distinguished from retail sales to consumers. In California (with food exempt and machinery taxable), Hickman found that 30 per cent of the state retail sales and use taxes were paid by businessmen on goods consumed in the conduct of their business. ${ }^{49}$

Administrative considerations militate against complete exemption from a federal tax of all sales for business use. The 1943 Treasury Department study of retail sales taxes observed:

While there is good reason for restricting the tax to sales to individual consumers, in practice it would be virtually impossible from an administrative standpoint to avoid inclusion of many sales of articles used by business concerns. The basic source of the difficulty is the fact that a great many articles can be used either for production or consumption purposes. . . . Accordingly, it would not be feasible to exempt all sales to business

${ }^{48}$ State Sales Tax Administration, Ch. 1.

${ }^{49}$ Distribution of the Burden, pp. 9-10. 
concerns either by exclusion of all classes of articles which are sold for use by business concerns, or by exclusion of all sales actually made to such concerns, regardless of the nature of the article sold. ${ }^{50}$

The lines between taxable and nontaxable business articles, however, involve troublesome distinctions. As a general rule, state laws exclude purchases of goods made for the purpose of resale, including materials or parts which are physically incorporated into property for resale. The usual practice is to tax industrial machinery in its final use, even though it produces goods for resale. The attempt to confine exemption of machinery to manufacturing operations creates problems, but broadening of exemptions to types of machinery wherever used would narrow tax bases now employed, and for some items would merely move the line of demarcation between taxable and nontaxable down to the retail level. Even where manufacturing equipment is exempt, tax typically applies to equipment used for administrative or distributional purposes.

Items that are directly used up in production but do not become physical elements of products - consumables-are provided varying degrees of exemption in about half of the states, and are fully taxable in the others. Industrial fuel is exempted in whole or in part in twenty states, although some which exempt consumables tax fuel. When consumables and fuel are exempt, the use of resale certificates is required for those who purchase tax free. In some states, administrative problems are avoided by exempting all fuel; in others administration is complicated by exempting only industrial fuel, necessitating rather arbitrary allocations where fuel is used both for manufacturing operations and the heating of offices and other buildings.

The sales tax treatment of agricultural production is also complex. All of the states exempt some goods used in farming, but treatment varies as to exempt items and whether they are exempt only for direct use in farm production or generally exempt. The problems range through such items as fuel, farm machinery, tools, feed, seed, plants, trees, livestock, poultry, insecticides and fertilizer. While taxing production items is not consistent with the concept of a retail tax, control of exemption of many items for farm use is difficult. The number of farmers is relatively large, many of them carry on rather small operations, usually they are not registered vendors, and it is not practicable to audit them.

${ }^{50}$ "Considerations Respecting a Federal Retail Sales Tax," U.S. Congress, House of Representatives, Ways and Means Committee, Hearings on Revenue Revision of 1948, 78th Cong., 1st Sess., p. 1129. 


\section{EQUITY, ADMINISTRATION AND COMPLIANCE}

\section{ADDITIONAL RETAIL SALES TAX PROBLEMS}

In addition to the problems of exempting items in the interest of equity to consumers and of appropriate taxation of goods used in production, administrative problems are encountered with other types of exemptions. Imposition of a sales tax on purchases by the federal government would provide no net revenue gain. It would increase costs of goods and services for governmental agencies, and would involve some administrative expense in the handling of additional tax collections. A federal tax imposed on business firms which sell to state and local governments might avoid constitutional issues, but it would aggravate the problems of these governments in financing their functions and would increase state and local taxes. Despite these considerations, the serious administrative problems resulting from exemption of all sales to governments might make taxation of such sales advisable. ${ }^{51}$ The loss of revenue through evasion and the administrative costs to business and government of handling exempt sales might be deemed to offset the disadvantages of taxation.

Similar problems arise with purchases by religious, charitable, and other nonprofit organizations. To the extent a sales tax bears on these institutions, it restricts their use of funds and they require additional support. But exemption creates serious enforcement problems, since there are large numbers of such organizations, and they frequently purchase from retailers in small quantities.

Where governments act as sellers of commodities or services that are taxable when supplied by private industry, there is little justification for exemption.

The adoption of a retail sales tax would require additions to federal administrative machinery, new forms, and new procedures. Opportunities for integration with income tax procedures seem limited. The states have typically operated their sales taxes through separate administrative divisions; only two states integrate sales tax and income tax organizations. Varying efforts have been made to combine some field functions in administration, but it has been found that audit work is highly specialized by type of tax. ${ }^{52}$

Some offsetting reductions in federal work load could be achieved with a general tax replacement of several existing selective excises, but on balance more extensive enforcement organization would be needed than for collection from relatively few manufacturers. With replace-

${ }^{51}$ Cf. "Considerations Respecting a Federal Sales Tax," pp. 1145-1147.

${ }^{52}$ See John F. Due, State Sales Tax Administration, Chapter II. 
ment of a significant part of individual income tax, a number of individual taxpayers might be dropped from tax rolls. This offset in lightening administrative burdens, however, would be relatively small, since these taxpayers would be in lower income brackets, file simple returns, and have their income tax liabilities discharged largely through wage withholding.

Much of the cost of operating the tax system falls on the business community under a sales tax, as it does under an income tax with withholding. Extra record keeping is required. The extent of compliance cost will vary with the rules that are established and with the rigor of their enforcement. Sales tax compliance in practice frequently seems rather crude. But acceptable approximations may in many instances be preferable to precision that can come only at much greater cost.

The need for adequate records is accentuated by tax exemptions. Where tax is not properly applied, the purpose of an exemption is defeated and there is usually a loss of revenue, since exempt sales to customers tend to be overstated. But the problem of the merchant operating with low paid help and selling both taxable and nontaxable items in rush hours is severe. In several states where food is exempt, grocery stores are permitted to estimate their tax liability each month on the basis of formulas related to gross receipts or purchases of taxable and nontaxable items.

A careful accounting of goods purchased for use by the firm itself is also difficult. Businesses of all sizes may use items-particularly operating and maintenance supplies-originally purchased tax free under a resale certificate. Records of transfers from inventory to taxable business use are often incomplete. Particularly for small retailers there is a similar problem with transfers from stock to personal use. And there is apparently some deliberate abuse of resale certificates in the wholesale purchase of household items, such as TV sets, for personal use of the retailers. Catching such items is not easy either by auditing the records of wholesalers whose typical transactions are exempt for resale, or by auditing the accounts of the retailer. ${ }^{53}$

If the federal government were to impose a retail tax of 10 per cent,

${ }^{53}$ Accounting difficulties were pointed out by some business respondents in the Canadian study of The Costs of Tax Compliance (p. 6). One noted: "The actual cost of complying with provincial and municipal sales tax is not only the mere compiling of tax figures but includes estimated expenditures which we are required to make in order to distinguish taxable from non-taxable sales." Another objected that: "The amount of time and detail required to (a) pay Federal Sales Tax on purchases and (b) prepare and suffer detailed audits of drawbacks is a very wasteful procedure." 
in addition to state taxes that now run up to 5 per cent, the premium for evasion or overstatement of exempt sales would be enhanced. As experience was gained some balance would have to be struck among the broad alternatives of (a) requiring suitable records of all businesses that would facilitate accurate checking of tax liabilities, (b) putting a greater burden of enforcement on the government in working with existing systems of business accounts, or (c) relying, as some of the states do, largely on voluntary compliance.

The imposition of either indirect taxes or income taxes upon business necessarily involves a considerable amount of office work. A retail sales tax differs, however, in that the task of compliance extends from the accounting office down to the clerk at the counter. Studies by such businesses as J. C. Penney Company, which pays sales taxes in many of the states, indicate that the "office cost" is a small proportion, 5 to 10 per cent, of the total cost of compliance. ${ }^{54}$ The great bulk of the cost to the firm is in the aggregate time taken by thousands of clerks in adding tax on hundreds of thousands of transactions - reading from tax collection charts, computing the tax, or punching the tax key on cash registers. With a view to minimizing their own expense, the J. C. Penney Company has endeavored to measure these costs through calculations based on stop-watch timing of clerks in rush hours, the average sale, and the average hourly wage of salespeople. It was found, for example, that where the average sale was $\$ 4.43$, the average hourly wage $\$ 1.50$, and 10 seconds was the average time used in recording tax, the total cost to the business of collecting a 2 per cent sales tax would be 5.02 per cent of tax collections. Presumably a 10 per cent sales tax could be collected under these conditions for about 1 per cent of the payments made to the government. Similar studies by the Bureau of Business Research, Ohio State University, indicated that "collections costs range from 2.55 per cent to 20.60 per cent of the tax collected from customers depending on the type of business involved." ${ } 5$

Whether total compliance costs for sales taxes are more or less than for income taxes is not easy to say. For 1961 nearly 62 million individual income tax returns were filed in the United States and, judging by newspaper comments in mid-April, this represents a troublesome chore for taxpayers. For many persons, who can rely on wage withholding receipts and simple tax forms, reporting is not difficult, but for others, with

${ }^{54}$ J. L. Fisher, "How Much Does It Cost to Collect Sales Tax?" Proceedings of the National Tax Association for 1961, pp. 619-625.

${ }^{65}$ Ibid., p. 621. 
business and investment income and with eligibility for itemized personal deductions and tax credits, the completion of Form 1040 is time consuming. In addition, more than a million corporations filed income tax returns in 1960-61, and a good deal of the burden of individual income tax compliance is borne by the business community through the payroll withholding system. Fewer tax returns would be required under a retail sales tax than under the income taxes. Of the 11.2 million business organizations in the United States, perhaps considerably less than half would have to register under a sales tax, depending upon the form of tax and exemptions allowed. But the compliance burden that extends down to the clerk and the customer in each retail transaction may well in the aggregate involve economic and social costs that exceed those of income tax returns.

In the choice of a general sales tax base that might be employed by the federal government, these compliance and administrative costs deserve careful consideration. Compliance would be more costly if there were differences between federal and state laws in coverage and exemptions, in lists of government agencies and nonprofit organizations that purchase tax free, and if state and federal taxes were to be reported separately on each receipt.

\section{GENERAL MANUFACTURERS AND WHOLESALE SALES TAXES}

Some problems encountered with a retail tax, in particular the large number of vendors, would be eased if a federal sales tax were to be levied at the manufacturers' or wholesale level. Either of these would provide a considerably narrower potential tax base, because prices are lower than at retail and because the service industries that might be reached at retail would almost of necessity be excluded from a manufacturing or wholesaling tax.

Selective manufacturers' sales taxes have administrative advantages, usually being concentrated on a relatively few taxpayers who keep adequate records. A broadening of a manufacturers' sales tax, however, can result in a diffusion of administrative effort and so intensify problems inherent even in selective taxes as to raise serious doubts about net administrative advantages of the general manufacturers' form of levy.

A selective tax requires precise definitions of products. Some, such as gasoline, may be defined with reasonable precision by physical or chemical specifications. Others, such as automobile parts and accessories, require numerous specific rulings as new products are developed or old ones varied. It is sometimes assumed that definitional problems would 
be largely avoided by a general manufacturers' tax. However, the experience of other countries and of the states demonstrates the practical impossibility of imposing a truly general tax at any single level of economic activity-manufacturing or retail. General taxes in practice contain important exemptions, and difficulties in delineating taxable from nontaxable items tend to be as great, or greater, than with selective taxes.

Manufacturers' taxes require determination of what is "manufacture" and who is a "manufacturer." The United States tax law, with deliberate intent, contains no definition of these terms, except for special provisions relating to gasoline. The Treasury Department has resisted proposals for statutory definition of a manufacturer in order to adapt interpretations to changing details of specific operations, but the Department has indicated that certain activities come within the scope of the term. ${ }^{56}$ For example, producers of taxable articles from scrap or junk are considered manufacturers and, accordingly, sales by rebuilders of parts, especially important in the automobile industry, are taxable. ${ }^{57}$ Production of a taxable article by assembling two or more other articles qualifies the assembler as a manufacturer. On the other hand, a producer who sells a taxable article in a knockdown condition, but complete as to all components, is liable for the tax, and not the person who buys and assembles the article from the parts. A patent owner who contracts for manufacture of his patented product by another and controls the production is considered the manufacturer. ${ }^{58}$

Under the Canadian manufacturers' sales tax of 11 per cent, a manufacturer includes a person who assembles parts into a complete product. Thus a machinery wholesaler, who assembles several major components into a unit, pays tax on his selling price rather than on cost of components, even though assembling is a minor operation. The tax may apply on the retail price of furniture if minor changes in styling are made to suit a retail customer. In general, mere bottling, labeling, or repackaging of bulk goods is not regarded as manufacturing, but there are important exceptions for candy, confectionery, pharmaceuticals, and toilet goods. ${ }^{59}$

In the United States, this type of problem led to the application of

${ }^{56}$ U.S. Treasury Department, Regulation 46 (1940 edition as amended through December 1956), sec. 316.4.

${ }^{57}$ This position was upheld in Clawson and Bols, Inc. 182 F. 2d 402, cert. denied, 340 U.S. 883; and Armature Exchange Inc. 116 F. 2d 969, cert. denied 313 U.S. 573.

${ }^{58}$ Polaroid Corp., 235 F. 2d 276, cert. denied, 352 U.S. 953.

${ }^{59}$ Some of the distinctions are discussed by W. D. Goodman, "A.B.C.'s of Federal Sales Tax," Report, 1962 Conference, Canadian Tax Foundation, pp. 61-65, and $\mathrm{H}$. O. Spindler, "Corporate Sales Tax Pitfalls," Corporate Management Conference, Montreal, 1963, Canadian Tax Papers, No. 34, pp. 3-12. 
selective excises on furs and jewelry at the retail level, since it was found that a great many retailers engaged in essentially manufacturing operations such as making, altering, or remodeling fur coats or setting stones in rings and making custom jewelry. ${ }^{60}$

A determination of what is manufacturing is also complicated by the varying scope of distribution functions performed by manufacturers. Some manufacturers conduct national advertising and marketing campaigns and sell directly to retailers or even at retail themselves. Others are practically production subsidiaries of large retailers who carry all the costs of distribution. Wide differences in distribution methods are reflected in different manufacturers' selling prices, and create competitive inequities if tax is imposed at the actual selling price of the manufacturer. Efforts to "equalize" the tax base involve problems of identifying comparable functions and establishing comparable values.

The lowering of a manufacturer's selling price by the splitting off of some distribution functions has been a cause of controversy in Canada with respect to private brands. A separate distributor may take over national advertising, research, design development, warranty, and other functions usually performed by a manufacturer. The manufacturer's taxable price is then lower for the private brand than for similar products bearing a manufacturer's label. ${ }^{61}$

Comparable problems are encountered in trying to keep tax on domestic manufacturers and imports on a par. In some cases domestic manufacturers may cover full costs of marketing operations, while for similar imports the sales effort is made after importation and payment of tax. The balance may swing the other way for imports for final consumers, where the tax base becomes the full retail price.

In the United States, the possibilities of splitting up functions often carried on by manufacturers led to a 1941 decision to shift the selective excise on toilet preparations from the manufacturing to the retail level. ${ }^{62}$

The question of equalizing manufacturers' taxable prices was reconsidered by the Congress in $1955-57 .{ }^{63}$ As a result, some changes were made in rules for constructive tax bases as part of the Excise Tax Tech-

${ }^{80}$ U.S. Congress, House of Representatives, The Revenue Bill of 1941, Report of the Committee on Ways and Means, 77th Cong., 1st Sess., section V, 5.

${ }^{81}$ M. J. Gorman, "A.B.C.'s of Federal Sales Tax," p. 56. Spindler in Corporate Management Conference, p. 4, notes that, "For one medium-sized firm, the annual tax saving from such an arrangement amounted to some $\$ 60,000$."

${ }^{82}$ U.S. Congress, House of Representatives, The Revenue Bill of 1941.

${ }^{83}$ U.S. Congress, House of Representatives, Excise Tax Technical and Administrative Problems, 3 vols., and Excise Taxes, Hearings before a Subcommittee of the Committee on Ways and Means, 84th Cong., 1st and 2d Sess. (1955-56). 
nical Changes Act of 1958. The investigating committee reported, "It is recognized, however, that there are significant administrative problems which make it difficult to achieve complete uniformity of base for purposes of the manufacturers' excise tax. For that reason no attempt is made in this bill to fully achieve this goal." ${ }^{64}$

The constructive price provisions are complex ${ }^{65}$ and interpretive rulings differ for items such as passenger cars, trucks, business machines and matches. In general, constructive prices may be required for manufacturers' excises where an article is first sold at retail or on consignment, or at less than fair market price if a transaction is not at arm's length. The constructive price is that deemed to be the price for which such articles are sold in the ordinary course of trade as determined by the Secretary of the Treasury or his delegate. This generally results in downward price adjustments for items sold by manufacturers at retail and in upward adjustments where transactions are between interrelated companies for less than a price that would obtain in an arm's length transaction.

The Canadian manufacturers' sales tax law does not provide constructive price rules but the Minister of National Revenue is empowered to adjust prices where he deems them less than fair, and the Department of National Revenue has developed rules for lowering the taxable price where manufacturers' sales are made to retailers or to consumers. The Canadian Sales Tax Committee in 1955 sought to find statutory language for general guidelines in areas where manufacturers' sales were not made to independent wholesalers in representative quantities, but the suggestions entertained were so ambiguous and uncertain that the Committee recommended leaving the matter to agreement between taxpayers and administrators. ${ }^{66}$

After considering these problems, the Canadian Committee recommended in 1956 that, as a longer-range goal, the general manufacturers' sales tax should be transferred to the wholesale level, in effect to be based on prices charged to retailers. Questions of how to define assembly, rebuilding, and production for patent owners usually would be avoided since tax would generally apply after these functions had been performed. But other problems of defining a uniform tax base would arise to the extent that retailers performed functions similar to wholesaling

${ }^{64}$ Excise Tax Technical Changes Act of 1957, Report of the Committee on Ways and Means, 85th Cong. 1st Sess., p. 21.

${ }^{65}$ See Internal Revenue Code, section 4216.

${ }^{66}$ Report of the Sales Tax Committee, Ottawa, 1956. 
or manufacturing, or held patents on products made to their order. As a result, upward adjustments in the price to the retailer would be needed to prevent discrimination against nonintegrated operations. Prices to retailers might also warrant adjustments if there were substantial variations because of quantity discounts or delivery charges.

General wholesale sales taxes are employed in such countries as Australia, New Zealand, and Switzerland. In Australia, for example, the tax applies to the actual selling prices to retailers. While this results in significant differentials between retailers who buy in large lots from manufacturers and those who buy in small lots from wholesalers, the discriminations do not seem to have been of serious concern to the Australians. ${ }^{67}$ But to Canadians, who have long tried to minimize discriminations, the proposed shift of tax base to the wholesale level had little general appeal. Retailers large and small opposed it, and the Minister of Finance in his 1957 budget speech pointedly declined recommending any change in the direction of basing the Canadian tax on the retailer's purchase price. ${ }^{68}$

There seems to be increasing recognition in Canada that reform of their sales tax system might best take the direction of a shift to the retail level. Professor Due, for example, has offered the following general observation on the Canadian system:

Review of the problems of taxable price, private brands, relative burdens on imported and domestic goods, and the choice of the manufacturing or wholesale level leads almost inevitably to the conclusion that forms of sales taxes imposed at a stage prior to the final retail sale are to an increasing extent the victims of economic progress [diversification of distribution channels, growth in private brands, and decline in importance of list prices]. Not only is complete equity among various firms impossible of attainment, but the problems are likely to become more troublesome over the years. ${ }^{69}$

The serious disadvantages of general manufacturers' or wholesale sales tax would seem to be compelling with respect to proposals for general sales taxes in the United States. When such proposals were under consideration early in World War II, a Treasury Department study concluded that, if a sales tax were to be employed, the retail level was

${ }^{67}$ Cf. John F. Due, "Report of the Sales Tax Committee: One Year in Retrospect," Canadian Tax Journal, March-April 1957, p. 98.

${ }^{68}$ As reported in "Fact and Opinion," Canadian Tax Journal, March-April 1957, p. 87.

68 "Report of the Sales Tax Committee: One Year in Retrospect," pp. 103-104. See also Ronald Robertson, "What Do We Want of Our Tax System?", Canadian Tax Journal, July-August 1962, p. 235; J. W. M. Dixon, "Provincial Sales Tax Uniformity," Report, 1962 Conference, Canadian Tax Foundation, pp. 339-343. 
to be preferred. ${ }^{70}$ While retail taxes have administrative disadvantages, such as a larger number of taxpayers, these disadvantages were deemed to be outweighed by the avoidance of pyramiding, problems of valuation and determining taxable transactions, and by achievement of a more uniform distribution of tax.

\section{VALUE-ADDED TAX ADMINISTRATION AND COMPLIANCE}

The form that a value-added tax might take in the United States is conjectural, but presumably it could be administered as an adjunct or partial replacement of existing income taxes. Corporation income tax returns and individual returns for farmers, sole proprietors, and partnerships could be expanded to provide the selected measure of value added. In general, this would require accounting for gross receipts and for deductions allowable for purchases from other business firms.

Treatment of some interfirm transactions for use of resources can vary. As sometimes conceived, the tax base would be receipts less costs of materials and other physical objects purchased, but without deductions for interest, rent, or service payments to other firms. ${ }^{71}$ It seems preferable and more consistent with a cumulative system of value added, for each firm to pay tax only on value added by its own labor, real estate, capital, and management, and for all interfirm payments to be excluded by the purchaser and brought into the value-added computation of the supplier.

The same tix base for a firm can be derived either by the subtraction method (gross receipts less excludable payments to other firms) or by the addition method of summing up profits and includable payments for factors employed by the firm. Either method requires systematically distinguishing payments to firm employees and owners from payments to outsiders. This may entail adjustments in the way some businesses account for costs of goods sold, so that direct labor costs and other intrafirm expenses are readily identifiable. Which method would prove more satisfactory for various industries is difficult to say and probably alternative sets of computations would be permitted to ease compliance. Alternatively, the tax can be calculated, as in France, by deducting value-added tax paid on purchases from tax due on sales.

70 "Considerations Respecting a Federal Sales Tax," pp. 1115-23.

${ }^{71}$ Cf. John F. Due, Sales Taxation, Urbana, Ill., pp. 125-126. The base is defined as "the difference between the cost of the materials and other physical objects purchased for use in production and the selling prices of the products." The proposed Japanese tax would also have allowed deductions for services purchased from firms. M. Bronfenbrenner, "The Japanese Value-Added Sales Tax," National Tax Journal, December 1950, pp. 298-313. 
One of the main appeals of the value-added tax approach is its potentially broad coverage of private productive activities and its economic neutrality among business firms. Some of the unneutralities of the existing system of income taxes have been attributed to (a) differences in treatment of corporate and noncorporate business sectors, particularly the relatively light taxes on personal services, real estate and housing, and agriculture $;^{72}$ and (b) differences in treatment of the effcient and profitable firms as compared to the inefficient. ${ }^{73}$ Under a general value-added tax, returns should be filed by all business organizations. In 1960-61 this would have comprised 9 million proprietorships, 941 thousand partnerships and 1.1 million corporations, a total of about 11.2 million business organizations. ${ }^{74}$ Except for the inactive firms, tax would be paid by those with net losses as well as those with profits. The tax would be distributed among businesses according to incomes earned therein, with the main determinant being payrolls, since labor and management services account for somewhat more than three-fourths of the total incomes.

While the impact of a consumption value-added tax would be spread throughout the various stages of production, the tax rate would approximate that of a retail sales tax for equal yield. The value-added tax rate would be lower to the extent that the tax could apply to more professional services, and exemptions of particular consumption items could be avoided.

The value-added tax would be amenable to a current payment system on an estimated basis, with final adjusted liability for the year being established through an annual tax return. Monthly or quarterly deposits of approximate liability could be made as is now done with income tax. Estimates based on standard ratios of value added to sales for various industries could be used for current deposits, probably with less error than occurs for estimates of the more volatile net income base.

Some income tax problems would be avoided or minimized under the value-added approach. There would be no need to determine, for closely held corporations, whether payments to manager-stockholders were really wages or dividends since they would be equally includable in the value-added base. All payments of salaries, wages, commissions, fringe benefits in pension funds, sick pay, health insurance, group term life

${ }^{72}$ Arnold C. Harberger, "The Corporation Income Tax: An Empirical Appraisal," and "The Incidence of the Corporation Income Tax."

${ }^{73}$ Dan Throop Smith, statement to Committee on Ways and Means.

${ }^{74}$ Statistics of Income, U.S. Business Tax Returns, 1960-61, U.S. Treasury Department, Internal Revenue Service, p. 3. 
insurance, deferred compensation, and stock options would presumably be payments to or for employees, reflecting value added in the firm; tax would apply at the firm level to this whole portion of the tax base.

Many problems of the income tax type would remain. For example, the treatment of entertainment expense accounts and business gifts would probably continue to be troublesome and would be subject to interpretation as to whether they represented business purchases, or utilization of income by the owners or management for personal purposes.

With the allowance of depreciation under an income value-added tax, there is the question of whether it should be on a basis which measures current costs and income or whether the allowance should contain elements of incentive to stimulate capital investment as the income tax has come to do. If depreciation and not expensing is to be allowed under an income value-added tax, should the special allowances for expensing that have developed under the income tax be carried overi.e., capital outlays for research and experimentation, soil and water conservation, mine exploration and development, intangible drilling and. development costs for oil and gas wells?

While, from the standpoint of national income accounts, capital gains are disregarded as not representing current value added by production, it is doubtful that this treatment is appropriate for value-added tax purposes, so far as capital gains on depreciated assets are concerned. And a set of rules somewhat comparable to those under an income tax would seem desirable for the handling of tax bases for assets in business reorganizations and mergers; capital assets expensed by one corporate entity could scarcely be permitted to be expensed by a second entity merely upon reorganization of business structures.

In most instances, under the subtraction method of determining value added, business losses would automatically be taken into account. Under the addition method, specific deductions would be necessary in calculating the tax base. ${ }^{75}$ In most cases the operating net loss to a firm would probably be a small proportion of the total value added reflected in payrolls and the use of capital. The outright expensing of capital assets, however, might result in substantial negative figures for current value added, and allowances for loss carryover to several other years would seem appropriate.

In designing a value-added base a number of questions would have to

${ }^{75}$ The extreme of the objective of neutrality between efficient and inefficient firms suggests that net losses should not be permitted to reduce the value-added base. 
be resolved about the deductibility of other taxes from gross income. The value added by the firm in employing labor presumably covers full labor costs including employer contributions through payroll taxes for social security and unemployment compensation programs, as well as private wage supplements through various fringe benefits. Accordingly, deductions might not be allowed for these taxes. A firm's property, sales, and income taxes are not like payments made to other firms on which value added will be taken into account by the supplier of goods and services. In part, payments of taxes are for facilities supplied by the community-sewerage, access roads, police and fire protection. To the extent that some industries supplied these types of services themselves, they would be reflected in the value-added base. If they purchase alternative services from outside firms, presumably they would be excluded from the value-added base. The deductibility of corporation income taxes that are imposed at different rates, or of progressive income taxes by individual proprietors or suppliers of professional services, would distort the measure of value added. Perhaps a more uniform treatment would be provided by disallowing the deduction of any tax payments (or including them under the addition method) in determining the valueadded tax. This would be simpler, and would make possible a lower value-added tax rate for the same revenue yield.

Charitable contributions by businesses are also covered by the total value added in business operations. Their deductibility would probably seem warranted on social policy grounds. While the computation of value-added bases by business enterprises would involve most items of income and expense employed in determining net income, there are likely to be a number of differences in the treatment of items that would require different methods of computation on tax returns.

A value-added tax system would be made much more complex if effort were made to provide exemptions for the goods and services commonly exempted from retail sales taxes. This, of course, would defeat the objectives of uniformity and neutrality, and as the base was narrowed, higher rates would be required for any given revenue yield. There are also serious problems of implementing tax exemptions in a satisfactory manner. If food were to be exempt, for example, should farmers be exempt on their production of cotton, wool, tobacco, hops and oilseed products? If the farmer and the food processor were to be exempt, is it simply on the value added at their respective levels of production, or the full amount of their sales price, and should they be given tax-free purchase of the goods they buy from other firms to be used in food pro- 
duction? Under a value-added system the purchase price of a truck by a farmer, food processor, or distributor would reflect value-added tax upon mining, steel making, tire manufacture, and so on. A system of refunds to the food industry for accumulated value-added tax in purchase prices would be an administrative burden, and an attempt to allocate tax rebates to prior level producers for the sale of a tax exempt product would be exceedingly difficult. Moreover, the farmer or the processor may use the truck both in the production of tax-exempt food items and for the production of items that are not exempt. It is notable that under the French value-added tax system, enterprises selling exempt products are allowed no tax credit on items they purchase, and as a result they may feel worse off competitively than if they were taxed and were given full recognition for the prior taxes on purchases. For this reason the French oil refining industry, which was exempt on its sales, requested that it be subject to the tax. ${ }^{76}$

In many instances a uniform and neutral value-added tax is likely to be more of a direct than an indirect tax, especially if applied to farmers and other basic producers. It is argued that it must apply to small unincorporated businesses if the existing bias against corporations is to be removed. To remove the bias against efficient enterprises, the levy would apply to firms with and without net income. In the bulk, it would be a tax on labor services, and in many instances largely the labor of a proprietor and his family. ${ }^{77}$

\section{A BROADER-BASED PERSONAL INCOME TAX}

An alternative to greater use of indirect taxes is a much more broadly based income tax, applying to adjusted gross income without exemption. A low-rate tax on adjusted gross income would replace a significant amount of revenue now obtained from the more complex income tax with much less additional burden for enforcement and compliance than greater use of indirect taxes. A 4 per cent tax applied to adjusted gross income in 1960 would have yielded $\$ 12.6$ billion.

Careful observers of tax administration and compliance problems have been concerned with the complexities of proposals to extend the state sales taxes, and perhaps a federal sales tax, to include more of the service industries and other potential elements of a general tax base.

${ }^{76}$ Martin Norr, "Sales Taxes in Europe and Canada," p. 249.

77 Statistics of Income data show that a considerable proportion of unincorporated businesses are one-man or family enterprises (see U.S. Business Tax Returns, 1960-61, pp. 38-39). In such cases, the value-added tax would be largely a direct levy on the value added by the proprietor's own services and investments. 
In their estimation, much the same general results could be obtained by a low, flat-rate tax on all individuals' adjusted gross incomes, with less legislative, administrative and compliance difficulty. ${ }^{78}$

A low-rate tax on adjusted gross income of individuals would not exempt investment, but the tax could be imposed as a direct spendings tax by the exclusion of savings. This would, however, involve serious compliance and enforcement problems in the measurement of individual net worth at the beginning and end of the tax year to insure that the amount of savings excluded truly reflected net savings after adjustments for use of prior capital accumulations or for borrowing.

In the search for broader tax bases, however, the potentialities of the individual income tax also deserve consideration. The further use and adaptation of the established machinery for tax compliance and enforcement might be easier and generally as satisfactory as designing and operating a retail sales or value-added tax.

\section{Intergovernmental Fiscal Relations}

STATE AND LOCAL NEEDS AND THE USE OF INDIRECT TAXES

In a federal system the financing policies of one level of government affect the others, and the interrelationships must be of concern in developing major changes in tax policy. The same citizens are taxed at local, state, and federal levels. All taxes come out of the same general income stream, whether they are based on property holdings, sales transactions, or incomes, and the economy is affected by the combined tax take.

Because federal taxes are now two-thirds of the total, decisions at the national level may limit state and local tax action. With national emergencies and cold war, the capacities of states and localities to finance their customary functions may necessarily be circumscribed. Often, among the various objectives of tax policy, the effect on intergovernmental fiscal relations has had a subordinate role, but it has not been entirely ignored. During World War II, in the adjustment of federal income tax rates, Congressional tax committees gave some attention to state income tax structures; one reason a national retail sales tax was not adopted was that a majority of the states relied heavily on such

${ }^{78}$ See remarks of Charles F. Conlon, Executive Director, Federation of Tax Administrators, and Stanley J. Bowers, Tax Commissioner of Ohio, in the discussion of "Sales and Use Taxes," Proceedings of the National Tax Association for 1961, pp. $651 \mathrm{ff}$. 
taxes; further increases in the federal gasoline tax were opposed on similar grounds. ${ }^{79}$

Those who propose future tax revisions must take into account the interests of state and local governments, and the fact that the Congress will probably give considerable weight to those interests; "the resistance to any possible impairment of state financial independence is the rock on which many of the boats of federal-state fiscal reform have foundered." 80

If federal taxes based on retail sales or value added were strongly to be preferred on economic and other grounds, intergovernmental accommodations could be made. Several types of taxes are employed by all three levels of government; for example, income taxes, and taxes on motor fuels, alcoholic beverages, and tobacco products. Only a few taxes are not imposed by both state and federal governments. The states are barred by the Constitution from imposing customs duties, and the federal government is effectively precluded from direct property taxes. But in search of revenues over the years, different levels of governments have moved into areas first taxed by others. The federal government imposed taxes on property transfers at death, and gasoline excises, both of which had previously been looked upon as state taxes; the states have moved into income taxes and tobacco taxes, both of which had been predominantly federal provinces. If new federal indirect taxes were replacements for existing income taxes, there would be changes in tax burden distribution, but the total tax take would not be increased, and the problems of the states in competing for revenue bases would be less severe than with net additional taxes.

In assaying the pros and cons of greater federal reliance on indirect taxes, several features of intergovernmental relations may be considered. The following discussion outlines some dimensions of the issues involved.

There is general recognition that the national government, with broader jurisdiction and heavier taxes, can and should exercise restraint in the use of its power to tax. In 1955 the Commission on Intergovernmental Relations emphasized the importance of a division of governmental responsibilities and of maintaining the vitality of state and local governments. ${ }^{81}$ The Congress, in establishing the Advisory Commission

${ }^{79}$ Roy Blough, The Federal Taxing Process, New York, 1952, p. 446.

${ }^{80}$ Ibid., p. 454.

${ }^{81}$ The Commission on Intergovernmental Relations, a report to the President for transmittal to the Congress, June 1955, p. 96. On intergovernmental problems I have also had helpful suggestions from George C. S. Benson, formerly Research Director of this Commission. 
on Intergovernmental Relations in 1959, declared that one of the purposes of the Commission would be to "recommend methods of simplifying tax laws and administrative practices to achieve a more orderly and less competitive fiscal relationship between the levels of government and to reduce the burden of compliance for taxpayers." 82 The President's Commission on National Goals pointed out in 1960 the pressing problems the states have in raising sufficient revenue, and suggested that the federal tax power be used to bolster state revenue sources by providing a credit for state income taxes against federal income taxes. ${ }^{83}$ Recent studies of tax scholars have explored various means of increasing the financial capabilities of state governments through adjustments in federal, state, and local fiscal relations. ${ }^{84}$

The demands upon state and local governments for services are evident. The functions traditionally performed by these governments are affected by growing population, increasing urbanization, migration from areas of relatively low public services to areas of higher levels, mounting automobile traffic, desires for improved education, health and hospital programs, and insistence on increased quantity and quality of government services generally as standards of living improve. Increases in outlays for education have been conspicuous, but they have been matched in recent years by outlays for general government functions, including health, hospitals, police, fire protection, natural resources, local recreation, water supply, and sanitation. With urbanization, for example, there are shifts from outhouses to cesspools to sewage systems and expensive waste disposal plants, shifts in costs from private to public sectors, and higher standards of sanitation expected.

In recent years, relative increases in costs of state and local government have outrun those of the federal government. For the period 1950 to 1962 , while GNP increased 95 per cent, federal outlays in terms of cash payments to the public increased 150 per cent, state and local, 159 per cent. From 1955 to 1962, while GNP increased 39 per cent, federal cash outlays increased 53 per cent and state and local, 74 per cent. ${ }^{85}$ In the shorter period from 1955 to 1961 , state and local expendi-

${ }^{82}$ Public Law 86-380, 86th Congress, September 24, 1959.

${ }^{83}$ Morton Grodzins, "The Federal System," Goals for Americans, New York, 1960 , p. 278.

${ }^{84}$ James A. Maxwell, Tax Credits \& Intergovernmental Fiscal Relations, Washington, 1962. L. L. Ecker-Racz and I. M. Labovitz, "Practical Solutions to Financial Problems Created by the Multilevel Political Structure," Public Finances: Needs, Sources, and Utilization, Princeton for NBER, 1961, pp. 135-221.

${ }^{85}$ Economic Report of the President, January 1963, Tables C-1, C-58. 
tures for education and for general government functions both increased about 73 per cent. $^{86}$

Various projections have been made of the course of state and local expenditures and most of them indicate that, if general inflation is avoided, costs in 1970 will be about double those of $1960 .{ }^{87}$ There are wider ranges of opinion about the abilities of these governments to finance the anticipated expenditures. Dick Netzer, who counts on a favorable response of property tax revenues with rising incomes (income elasticity of 1.0 or more), believes the needs could be met by all states adopting the full array of retail sales, individual income, and corporate taxes now used by a few states, and by rather moderate increases in the rates now employed for those taxes..$^{88}$ Others are not so sanguine, and believe that not only would rate increases have to be substantial, but there may also have to be changes in intergovernmental fiscal relations that will enable the federal government to release or direct financial resources to the states..$^{89}$ If there were relative rises in the prices of goods and services purchased by state and local governments, their financial problems would be the more severe and they would be forced to rely on increased borrowing. At the least, it may be expected that substantial increases will continue to be sought in state and local tax collections, as there have been in recent years, through new tax enactments, higher tax rates, and efforts to improve tax administration. ${ }^{90}$

A considerable legacy of opinion in the United States has favored allowing the states leeway to increase their use of indirect taxes. The staff of the Advisory Commission on Intergovernmental Relations, in surveying fiscal capacities, notes that "The States are bound, not by federal law, but by tradition and circumstance, to rely heavily on property and consumption taxation and they cannot be expected to shift this reliance substantially in the foreseeable future." ${ }^{91}$ Groups that have

${ }^{86}$ Ibid., Table C-63.

${ }^{87}$ G. Colm and M. Helzner, "Financial Needs and Resources Over the Next Decade: At All Levels of Government," Public Finances, pp. 3-21; Dick Netzer, "Financial Needs and Resources Over the Next Decade: State and Local Governments," ibid., pp. 23-65; R. J. Lampman, "How Much Government Spending in the 1960's," Quarterly Review of Economics and Business, February 1961, pp. 7-17. ${ }^{88}$ In Public Finances, p. 63.

${ }^{89} \mathrm{Cf}$. Colm and Helzner, in Public Finances, pp. 20-21; and the comments of Manvel, Labovitz, Kahn, and Mushkin, ibid., pp. 65-77; see also James A. Maxwell, Tax Credits, p. 10.

${ }^{90}$ Cf. L. L. Ecker-Racz, "State and Local Tax Prospects for the 1960's," a paper prepared for the 1960 Conference of the Governmental Research Association.

${ }_{91}$ Measures of State and Local Fiscal Capacity and Tax Effort, p. 91. 
studied possible reallocations of revenue sources among levels of government have recognized the traditional relationships. In 1947, a Joint Committee of the American Bar Association, the National Tax Association, and the National Association of Tax Administrators proposed, in a comprehensive report, that taxes on general sales, amusements, admissions, gasoline, motor vehicle registration, and property transfers at death or by gift be reserved for state use. ${ }^{92}$ Similar recommendations have been made by the Special Committee on Federal State Tax Relations of the Governors' Conference (which included members of Congressional Tax Committees), 1947; the Governors' Conference; the Council of State Governments; the American Municipal Association; the United States Conference of Mayors; ${ }^{93}$ and the Joint Federal-State Action Committee (1957-59). Among the taxes commonly suggested for state and local use have been those indicated above and also those on local telephone service, cigarettes, club dues, coin operated devices, and safe deposit boxes.

These proposals have not resulted in significant action toward separation of revenue sources, perhaps partly because federal needs for revenue have remained high. The federal government has in recent years reduced its reliance on some excises by repealing taxes on electrical energy, on the transportation of all property and of persons other than by airlines; by various rate reductions; and also by exemption increases, which have been particularly marked in the admissions tax area. The states have not moved aggressively into the particular areas vacated by the federal government. But it is notable that the numerous suggestions for strengthening the financial capabilities of state and local government have been directed, outside of death taxes, to indirect taxes as being most suitably reserved for their use. A change in the opposite direction would have to overcome widely held opinions. It appears that a very strong tide would have to be running in favor of more general federal use of indirect taxes in order for such proposals to pass over the reefs represented by traditional views.

The use of indirect taxes (including motor fuel taxes) by all levels of government in 1961 is shown in Table 2. Just over half of the existing

92 The Coordination of Federal, State and Local Taxation, pp. 98-103.

${ }^{93}$ For a summary of various proposals, see L. L. Ecker-Racz, "Study and Action Relating to Federal State Tax Relations," Federal, State, Local Tax Correlation, Princeton, 1954, pp. 14-33, and "Practical Solutions to Financial Problems Created by the Multilevel Political Structure," in Public Finances. 
TABLE 2

REVENUES FROM ALL TAXES ${ }^{\mathbf{a}}$ AND FROM SALES AND GROSS RECEIPTS

TAXES, ALL LEVELS OF GOVERNMENT, 1961

(dollar figures in millions)

\begin{tabular}{lccrrr}
\hline \hline & $\begin{array}{c}\text { All } \\
\text { Levels of } \\
\text { Government }\end{array}$ & $\begin{array}{c}\text { Federal } \\
\text { Government }\end{array}$ & $\begin{array}{c}\text { State } \\
\text { and } \\
\text { Local }\end{array}$ & State & Local \\
\hline $\begin{array}{l}\text { All taxes } \\
\text { Percentage of all taxes }\end{array}$ & $\begin{array}{r}116,331 \\
100.0\end{array}$ & $\begin{array}{r}77,470 \\
66.6\end{array}$ & 38,861 & 19,057 & 19,804 \\
$\begin{array}{l}\text { Sales and gross } \\
\text { receipts taxes }\end{array}$ & 25,112 & 12,649 & 12,463 & 11,031 & 1,432 \\
$\begin{array}{c}\text { Percentage of sales and } \\
\text { 8ross receipts taxes }\end{array}$ & 100.0 & 50.4 & 49.6 & 43.9 & 5.7 \\
\hline
\end{tabular}

Source: U.S. Department of Commerce, Bureau of the Census, Governmental Finances in 1961.

axcluding employment taxes for insurance trust fund revenues.

total sales and gross receipt taxes were collected by the federal government.94

Table 3 shows the proportion of total tax revenues at each level of government attributed to indirect sales and gross receipts taxes for selected years. At the federal level the indirect taxes are relatively outweighed by the direct income taxes, and, in recent years, the indirect have been about one-sixth of total federal taxes. For the states, sales and gross receipts taxes have, since the 1940's, accounted for nearly three-fifths of total taxes, and the indirect taxes have become of increas-

${ }^{94}$ Classifications of government receipts as taxes or as indirect taxes may vary. The Census classification, for example, does not include employment taxes for insurance trust revenues as taxes, although for some purposes these levies on payrolls might be regarded as a form of income tax or perhaps a limited form of tax on value added by labor services. Among sales and gross receipts taxes, the Census classification includes customs and selective excises on particular products, but excludes license taxes on public utilities, corporations in general, occupations and businesses, alcoholic beverages and amusements, although these license taxes might for some purposes be regarded as indirect taxes imposed on business with much the same economic effect as gross receipts taxes. State severance taxes might also be regarded as a form of indirect tax, with the incidence falling in part on owners of the natural resources and in part on consumers of products. In a number of the states the net revenues from the operation of liquor monopolies are in lieu of heavier indirect taxes on liquor and possibly might be considered as equivalent to an indirect tax. But for general comparative purposes here, the Bureau of the Census classifications are followed. On this basis the federal government has recently been deriving slightly more than the state and local governments from indirect taxes. 
TABLE 3

PERCENTAGE OF OWN TAX REVENUES ${ }^{a}$ FROM TAXES ON SALES AND GROSS RECEIPTS, ALL LEVELS OF GOVERNMENT, SELECTED YEARS

\begin{tabular}{ccccccc}
\hline \hline & $\begin{array}{c}\text { All } \\
\text { Leve1s of } \\
\text { Government }\end{array}$ & $\begin{array}{c}\text { Federal } \\
\text { Government }\end{array}$ & $\begin{array}{c}\text { State } \\
\text { and } \\
\text { Local }\end{array}$ & State & Local & $\begin{array}{c}\text { C1ty } \\
\text { Government }\end{array}$ \\
\hline 1902 & 37.5 & 94.9 & 3.3 & 17.9 & -- & \\
1913 & 29.5 & 92.4 & 3.6 & 18.3 & .2 & \\
1927 & 16.5 & 32.3 & 7.7 & 27.7 & .6 & \\
1936 & 32.0 & 49.1 & 22.1 & 53.2 & 2.2 & \\
1940 & 32.4 & 43.6 & 25.4 & 55.9 & 2.9 & \\
1950 & 25.4 & 22.3 & 32.4 & 58.9 & 6.1 & \\
& & & & & & 15.8 \\
1957 & 20.9 & 15.9 & 32.9 & 58.1 & 7.2 & 15.6 \\
1958 & 21.4 & 16.6 & 32.4 & 58.7 & 7.0 & 15.8 \\
1959 & 21.8 & 16.8 & 32.2 & 58.6 & 7.0 & 17.1 \\
1960 & 21.6 & 16.4 & 32.8 & 58.3 & 7.4 & 17.0 \\
1961 & 21.6 & 16.3 & 32.1 & 57.9 & 7.2 & 17.0 \\
1962 & & & & 58.5 & & \\
\hline
\end{tabular}

Source: U.S. Department of Commerce, Bureau of the Census, Historlcal Summary of Governmental Finances in the United States, 1957 Census of Government s; Governmental Finances in 1961; Compendlum of State Government Flaances in 1962; Summary of City Government Finances in 1962.

axcluding employment taxes for insurance trust fund revenues.

ing relative importance to the cities, comprising more than one-sixth of their tax revenues.

The degree of reliance on sales and gross receipts taxes varies among the states, as is shown in Table 4 for 1962. The state tax systems are diverse. Thirteen of them impose no general sales or gross receipts taxes, while others obtain about half or more of their total taxes from such levies. All of the states employ selective sales taxes. All of them tax gasoline for motor fuel at rates of $5 \notin$ to $8 \notin$ per gallon; all tax beer; most tax liquor; and all but three, Colorado, North Carolina, and Oregon, tax cigarettes. In the aggregate, selective sales taxes account for about one-third of all state tax reserves, and general sales taxes for about onefourth. ${ }^{95}$

Table 5 gives frequency distributions of states according to the percentage of total tax revenues derived in 1961 from sales and gross

${ }_{95}$ Among the states which receive relatively low proportions of revenues from the general and selective sales taxes, significant amounts of revenue are derived from taxes not included as sales and gross receipts taxes under the Census classifications; for example, document and stock transfer taxes in New York; license taxes on corporations in Delaware, New Jersey, Massachusetts, and Texas; severance taxes in Louisiana, Oklahoma, and Texas. 


\section{EQUITY, ADMINISTRATION AND COMPLIANCE}

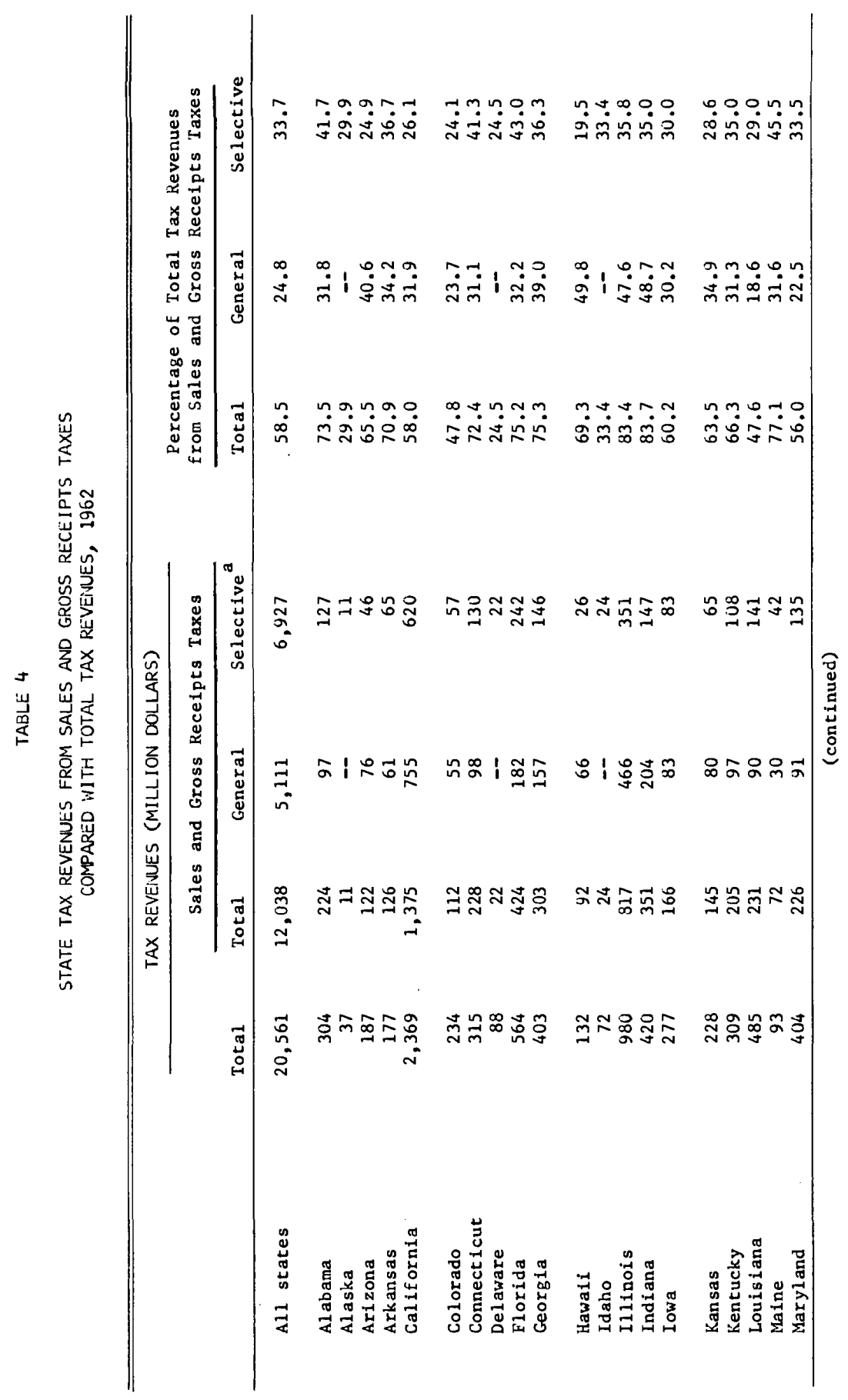


AND INTERGOVERNMENTAL FISCAL ASPECTS

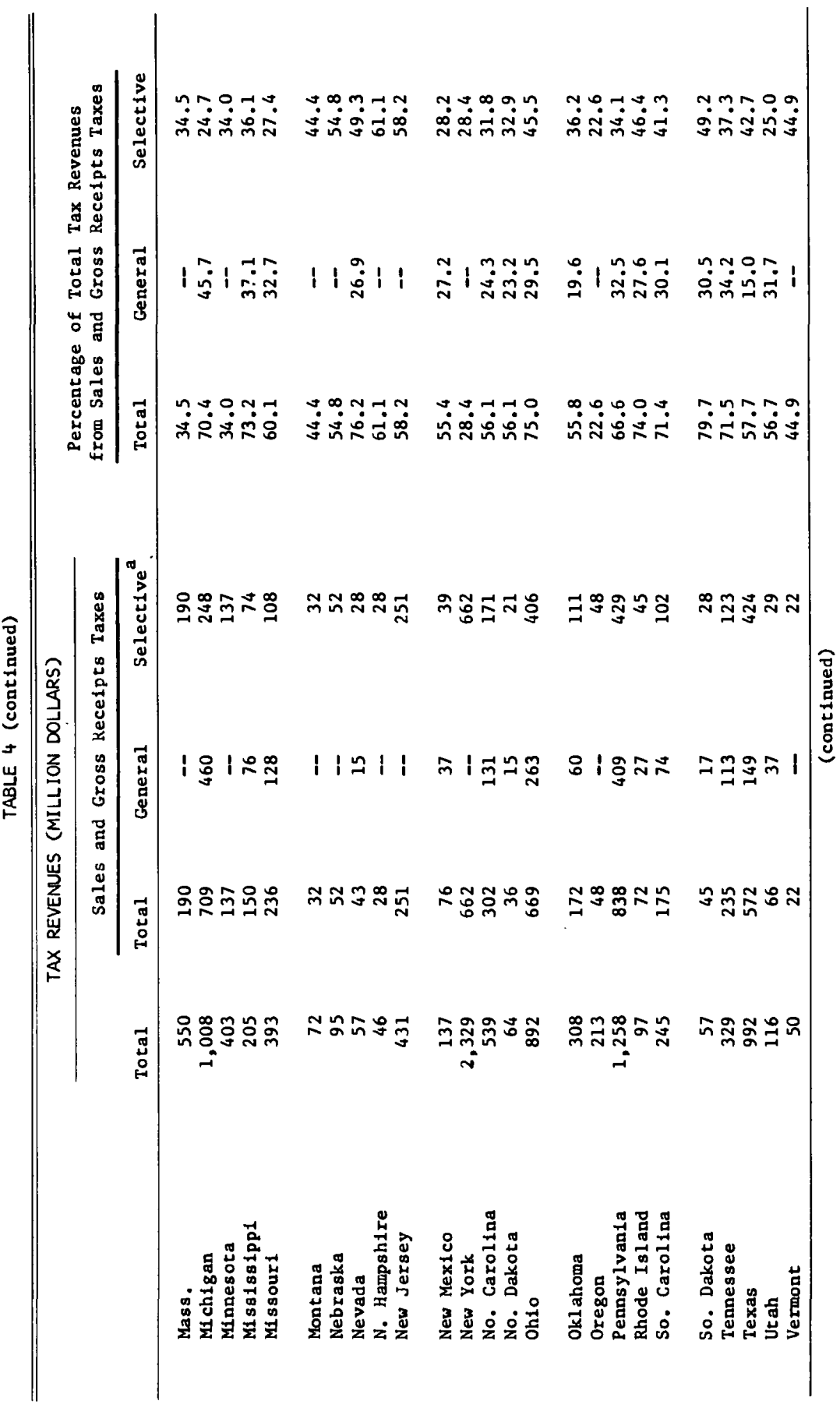


EQUITY, ADMINISTRATION AND COMPLIANCE

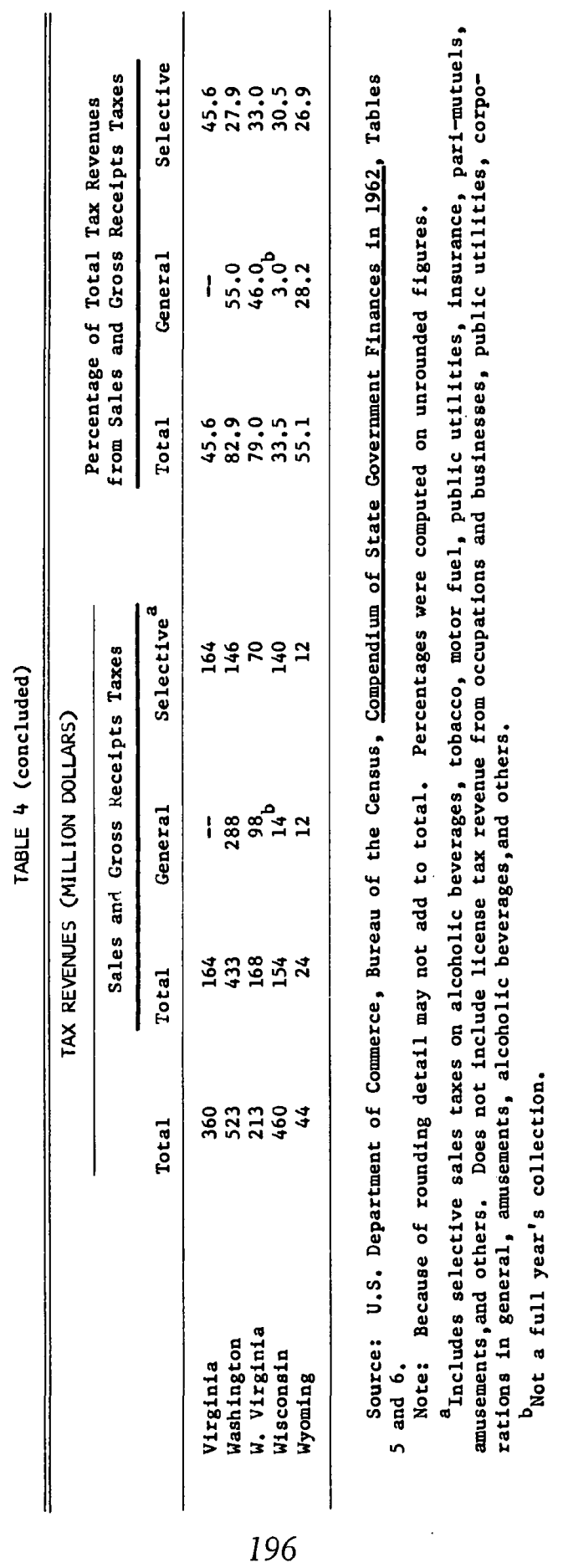


receipts taxes. Three states derive more than 80 per cent of their taxes from the various indirect levies; more than half the states get 60 per cent or more. Only one state obtains more than 50 per cent of total taxes

TABLE 5

FREQUENCY DISTRIBUTION OF STATES BY STATE TAX REVENUES FROM ALL SALES AND GROSS RECEIPTS TAXES AND FROM GENERAL SALES AND GROSS RECEIPTS TAXES AS PERCENTAGE OF TOTAL TAX REVENUES

\begin{tabular}{cccc}
\hline \hline $\begin{array}{c}\text { Percentage of Tax } \\
\text { Revenue from All } \\
\text { Sales and Gross } \\
\text { Receipts Taxes }\end{array}$ & $\begin{array}{c}\text { Number } \\
\text { of } \\
\text { States }\end{array}$ & $\begin{array}{c}\text { Percentage of Tax } \\
\text { Revenue from } \\
\text { General Sales and } \\
\text { Gross Receipts Taxes }\end{array}$ & $\begin{array}{c}\text { Number } \\
\text { of } \\
\text { States }\end{array}$ \\
\hline 80 to 85 & 3 & 50 to 55 & 1 \\
75 to 80 & 7 & 45 to 50 & 5 \\
70 to 75 & 8 & 40 to 45 & 1 \\
60 to 70 & 8 & 35 to 40 & 2 \\
50 to 60 & 11 & 30 to 35 & 5 \\
40 to 50 & 5 & 25 to 30 & 4 \\
30 to 40 & 4 & 20 to 25 & 3 \\
20 to 20 & 4 & 15 to 20 & $\overline{36}$ \\
\hline
\end{tabular}

aisconsin omitted because not a full year's collections.

from a general sales and gross receipts tax, but twenty-four states derive 30 per cent or more of all taxes from such general levies.

State use of general sales taxes began in the depression years of the 1930's, when twenty-four states adopted them. Between 1947 and 1955, ten more states, and since 1960, four additional states enacted this form of tax. The trend will probably continue.

Many of the states employing the tax have made significant rate increases. From 1953 to 1963 , nineteen states raised their sales tax rates. The median increased from 2 to 3 per cent and the top rate reached 5 per cent. Many of the rate increases are recent (five in 1961, four in 1963), and this trend may also be expected to continue. Several of the states have also modified their laws to include sales and services not previously taxed.

Prior to World War II only two major cities, New York and New Orleans, imposed retail sales taxes. After the war a local sales tax movement developed and has now spread to thirteen states and the District of Columbia (Alabama, Alaska, Arizona, California, Colorado, Illinois, Louisiana, Mississippi, New Mexico, New York, Tennessee (1963), Utah, and Virginia). Six of the fifteen largest cities in the United States (New York, Chicago, Los Angeles, Washington, San Francisco, and New Or- 
leans) impose sales taxes. Local rate increases have also been made; for example, in 1963 New York City raised its 3 per cent tax to 4 per cent; in 1962 the District of Columbia raised its 2 per cent to 3 per cent ( 3 per cent to 4 per cent on transient lodgings), and Denver 1 per cent to 2 per cent.

Selective sales taxes have also been under increasing pressure. The tax rates on cigarettes were increased by seventeen states in 1961, by two states in 1962, and by fourteen states in 1963. Alcoholic beverages were subjected to heavier taxes by nine states in 1961, by three states and the District of Columbia in 1962, and by five states in 1963. Gasoline taxes were raised in six states in 1961 and in five states in 1963. The pressure for revenues have also evoked larger yields from local property taxes, caused the extension of state and local income taxes, and prompted New Hampshire to turn to lotteries. But generally, the sales taxes have retained their relative position.

The states have demonstrated that they can operate general sales taxes, perhaps as effectively as the federal government could ${ }^{96}$ The larger municipalities have also made them work reasonably well, although separate taxes at state and local levels are certainly a nuisance for vendors and much is to be gained by the California system of having the state administer the tax for both levels. ${ }^{97}$ While there are problems with interstate transactions, the sales tax base is probably more accessible for the states than a net income base, and there seems to be less apprehension about migration of sales tax bases to lower tax areas than about incomes, especially large investment incomes. ${ }^{98}$

A substantial shift by the federal government to increase its reliance upon indirect taxes would hamper the abilities of the state and local governments to finance their growing needs. The states could not as readily modify their tax structures to obtain a significantly larger share of their revenues from income taxes, and to the extent they could move in this direction, they would be conflicting with the federal objective of placing greater over-all reliance on indirect taxes. Some increased yields may be expected from property taxes, but the states cannot be expected to return to this field which has been left increasingly to localities since the 1930 's. The capacity and willingness of citizens to contribute further

${ }^{96}$ Cf. Roy Blough, Federal Taxing Process, p. 452.

${ }^{97}$ John F. Due, State Sales Tax Administration, Chapter XI, "The Role of the State in Municipal Sales Taxation."

${ }_{98}$ Advisory Commission on Intergovernmental Relations, Measures of State and Local Fiscal Capacity and Tax Effort, a staff report, p. 85; Harold M. Groves, comments, Public Finances, pp. 222-223; James A. Maxwell, Tax Credits, p. 161. 
indirect taxes to state and local governments would probably be adversely affected as the federal government increased its demands in this area.

There might be offsetting factors. It may be argued that the adjustment of the federal tax structure would be conducive to more rapid economic growth and to increases in state and local tax bases that would ease their financing problems. But these expected effects are difficult to quantify in a manner persuasive to state and local officials or Congressional tax committees.

The problems now confronted by governors and state legislators in obtaining revenues by new sales tax enactments or by rate increases would be aggravated if the federal government were levying a sales tax of, say, 10 per cent. The problems would probably be somewhat easier if the federal levy were a value-added tax. They would also depend upon public understanding and reaction to the tax. But increased taxpayer resistance at the state and local level and perhaps more debt financing could be expected, even though the federal indirect tax were a replacement for revenues now obtained through income taxes.

In addition to increased competition for similar tax sources, progressivity in the over-all tax structure would be lessened-a consummation many devoutly wish-but this would probably accentuate questions of tax equity and the acceptability of particular taxes at the state and local level. Frequently objections to regressivity of state indirect taxes have been countered with the argument that these taxes are only one element in a combined tax system which has balancing progressive elements. In California, for example, Ronald B. Welch has pointed out:

It is the progressivity or lack of it in the total tax system, not in any one segment of it, which is of primary significance in policy determinations. Thus, although the State's excise tax system, standing alone, would not measure up to currently popular concepts of equity, it would appear to be a very useful part of the over-all tax structure of the federal-state-local governmental organization within which we live.99

A federal shift toward more indirect taxes would also lessen the significance of tax deductibility as an intergovernmental tax coordinating device. Deductibility of state taxes certainly cannot in itself be a justification for maintaining federal income tax rates, but it has long been recognized that these federal allowances have intergovernmental ad-

${ }^{99}$ Preface to Distribution of the Burden of California Sales and Other Excise Taxes. Cf. Wisconsin's State and Local Tax Burden, pp. 42-43, 101; W. D. Gardner, State and Local Taxes in the Northern Plains, Fargo, North Dakota, 1962, p. 27. 
vantages in diminishing tax differentials between states, curbing state tax avoidance by migration, and probably lessening taxpayer resistance to revenue increases at the state and local levels. ${ }^{100}$ Deductibility is one means by which the federal government assists in financing activities in the public interest, and its advantages to state and local governments come, of course, at a cost to the federal Treasury. ${ }^{101}$ Deductibility for state and local taxes would not seem feasible under a federal retail sales tax. Alternatively, perhaps state and local taxes would not be deductible in determining a value-added tax base; if they were, the deduction would be apparent to firms but probably not to individual citizens. As a result, the indirect support the federal government now affords state and local revenues would be curtailed, and increases in tax effort at these levels would probably encounter more resistance.

As was indicated in the previous discussion of administrative considerations, the exemption from federal sales or value-added taxes of all purchases by state and local governments would be troublesome. But unless they were exempt, or unless a system of intergovernmental refunds were developed, an indirect federal tax would raise state and local costs and further aggravate their financing problems. Professor Due has noted that in Canada "There are few aspects of the present [federal manufacturers sales] tax which give rise to more bitter and constant complaints than the application of the tax to the purchases of the financially hard-pressed municipal governments." ${ }^{102}$

\section{TAX COORDINATION}

In intergovernmental relations, the overlapping of taxes by different jurisdictions has long been recognized as a problem, ${ }^{103}$ resulting in duplication of administrative machinery and in complexities of compliance for taxpayer's who must deal with different tax forms, different rules and procedures, and sometimes a multiplicity of audits. The desires for autonomy and diversity of revenue sources at each level of government have resulted in levies on tax bases that are essentially the same but

100 U.S. Treasury Department, Committee on Intergovernmental Relations, Federal, State and Local Government Fiscal Relations: a report submitted to the Secretary of the Treasury, 78th Cong., 1st Sess., Senate document No. 69, 1943, p. 153; the report of The Commission on Intergovernmental Relations, p. 106.

${ }^{101}$ See Maxwell, Tax Credits, Chapter 5, pp. 96-125.

102 "Report of the Sales Tax Committee: One Year in Retrospect," p. 89.

${ }^{103}$ Federal, State and Local Government Fiscal Relations, 1943, p. 57 ff; U.S. Treasury Department, Overlapping Taxes in the United States, Washington, 1954; Advisory Commission on Intergovernmental Relations, Tax Overlapping in the United States, 1961, Washington, 1961. 
differ in particulars. To an objective observer interested less in autonomy than in efficiency and economy, the complexities that are developed, maintained, and proliferated in a federal system constitute sheer social waste.

Unless the federal government were to replace completely the individual income tax or the corporation income tax, the adoption of a general indirect tax would mean one more layer of taxation in the United States. The various layers at the federal level might be thinner to obtain the same aggregate revenues, but the advantages deemed to be obtained by greater diversity should be weighed against the additional costs in complexity.

A move toward federal general sales taxation would be in the opposite direction from some approaches often suggested for improving intergovernmental tax coordination. Hope for separation of revenue sources would apparently be abandoned. The scope would be narrowed for various proposals to assist state and local governments by allowing income or property tax payments to be credited against federal income tax.

A federal value-added tax would be a new form of tax that could be implemented by expanding business income tax forms and by increasing tax enforcement staff to insure through audits that the new tax operated effectively. A federal retail sales tax would also be a new tax in many respects; no two of the state sales taxes are exactly alike, ${ }^{104}$ and many of them differ widely in coverage. Wherever federal and state tax bases differed, the two taxes would have to be computed separately by sales clerks, and entered separately on sales records. Verification procedures by tax auditors would differ. A federal general retail sales tax would require new tax forms and procedures for businesses throughout the country, and quite different enforcement activities than are now conducted by the Internal Revenue Service.

Some state administrators have expressed misgivings about the additional overlapping that would arise with a federal sales tax. Dixwell $\mathrm{L}$. Pierce, former Secretary of the California State Board of Equalization, has noted for example that, while cooperative efforts have been satisfactory for selective sales taxes, such as on motor fuel collected from a few firms, the problems would be much more complex under general sales taxes, for which there are over 300,000 vendor accounts in California.

If the federal government should impose a comparable tax administered without regard to the state tax, as has been the practice heretofore when

${ }^{104}$ See Advisory Commission on Intergovernmental Relations, Measures of States and Local Fiscal Capacity and Tax Efforl, p. 7. 
that government enters a tax field occupied by the states, the jurisdictional conflicts that may be anticipated are legion. Conditions in the broad field of retail trade are far different from those that prevail in an industry as highly concentrated as the production of gasoline.

There is a constant change of taxpayers in the administration of a retail sales tax. Businesses are discontinued. Businesses are sold. New businesses are begun. Locations of stores are changed. Self-declarations of tax must be checked and steps taken to enforce such additional amounts as may be shown to be due.

As all too often is the case, discontinuances and changes may mean that retail businesses have not been conducted profitably. There may be insufficient assets remaining to meet sales tax obligations. If the federal government and the state governments are competing in their efforts to effect collections the states know from harsh experience that they are at a decided disadvantage. The supremacy of the national government gives it the right to complete realization of its tax claims before the states may effect collection of what is due them. Too often a state administration will invest in an audit of the liability of a retailer only to find that superior federal tax claims will so reduce assets of the taxpayer as to make the state determination unavailable. ${ }^{105}$

On the other hand, a separate federal value-added tax or general sales tax could provide a basis for tighter tax enforcement at both state and federal level through cooperative arrangements for exchange of tax returns and audit results. Considerable progress in cooperative income tax administration has been made since 1935 when Congress authorized state use of information from federal tax returns, although the achievements are still far short of potentials and the duplicate costs of compliance and administration remain. ${ }^{106}$ Effective cooperation on indirect taxes would put an obligation on many of the states to bring their administrative techniques up to a level that would enable truly joint efforts.

In the adoption of a general indirect tax by the federal government, two quite different approaches could be taken, and the choice would depend somewhat on the degree of intergovernmental tax coordination to be sought. The federal levy could be a separate tax, with frank acceptance of the problems of further diversity and tax overlapping in administration and compliance. Or the opportunity could be taken to try to bring about greater uniformity of the over-all tax structure.

The easier way for the federal government would be to introduce a new tax operated independently of state and local levies. A value-added

105 "Federal-State Tax Conflicts Can Be Minimized: A Discussion of Administrative Aspects," Federal-State-Local Tax Correlation, Princeton, 1954, p. 157.

${ }^{106}$ See Ecker-Racz and Labovitz, in Public Finances, pp. 175-179. 
tax could best be imposed upon all activities of a business as reported from its principal office without regard to the portions of the value added attributable to various phases of operations throughout the nation. Similarly, a retail sales tax could be operated on the basis of national tax returns without concern about the state in which sales were made. With this direct, national approach there need be no attention to possible tax credits or tax supplements for state and local governments.

On the other hand, some persons may see the adoption of a new federal tax as the occasion to implement proposals for a closer correlation of multi-level taxes. If less weight were to be given tax autonomy, uniformity might be realized under a new broad tax, with provision for revenue sharing or for state and local tax supplements levied on the same tax base. This could also increase reliance on indirect taxes, at the state as well as the federal level. Conceivably, for example, the federal government might impose a retail sales tax, of say 15 per cent, against which a credit of say 5 per cent, or one-third, would be allowed (or equivalent revenues shared) in states that adopted a conforming tax. ${ }^{107}$ To supplant existing state sales taxes the credit should be high enough to replace yields in the states currently relying most heavily on sales taxes. States without, or with lower, sales taxes would be under pressure to adopt conforming taxes, since the top federal rate would apply generally and be paid on transactions in each state whether the state availed itself of the credit or not. Tax coordination might be achieved at the cost of considerable state independence in determining their own tax systems. ${ }^{108}$

An indirect tax base that could serve toward revenue sharing or a tax credit on the basis of collections within each state would have to be segmented by state. Alternatively, revenue sharing could be based on a general formula for per capita distribution or equalization of federally collected revenues among the states. The sales tax states have sought increasingly to include within their jurisdiction the sales of goods consumed or used within their borders even though the goods come from out of the state. Where taxes on goods received from other states are not discriminatory as compared to intrastate purchases, the Supreme Court has sustained the jurisdiction of a state to require out of state vendors, with no permanent local establishment, to collect and remit

${ }^{107}$ Possible use of a federal sales tax credit, as well as an income tax credit, has bean suggested though not advocated by Joseph A. Pechman as a means of inducing all states to utilize both revenue sources. See James A. Maxwell, Tax Credits, p. 153.

${ }^{108}$ As L. L. Ecker-Racz has noted: "A tax forced on the states by the tax credit route varies from a grant-in-aid only in degree." See Public Finances, p. 174. 
the state use tax; this requirement has been deemed compatible with both the due process and commerce clauses of the Constitution. ${ }^{109} \mathrm{~A}$ retail sales tax base that would serve as a measure of both federal and state sales taxes would presumably require geographical allocation according to final use, or alternatively, a value-added tax might be based on amounts of value added attributed to each state. These alternative taxes would result in quite different distributions among the states, since the sales tax approach emphasizes the final destination and the value added, the origin of items subject to tax.

Unless some pressure were applied toward state conformity following adoption of a federal sales tax, it seems unlikely that a rapid, voluntary movement would develop among the states to lessen tax overlapping and duplication. The willingness of the sales tax states to go along with a uniform base would undoubtedly be increased if that base were determined according to the destination and final use of taxed items. ${ }^{110} \mathrm{But}$ there are many differences in existing sales tax bases, and even though the federal government undertook interstate allocation of the general sales tax base, state conformity to it would mean some loss of state autonomy and flexibility and, in many instances, a redistribution of tax burdens among persons in the state. Experience with tax coordination efforts in the inheritance and estate tax and income tax fields does not provide optimistic precedents, although some steps have been taken toward state adoption of the federal income tax bases. ${ }^{111}$ It is notable that, with the exception of Wisconsin, the state income tax systems were developed after adoption of the federal tax, whereas a federal sales tax would now come after the enactment of such taxes in 37 states, in many of which the sales tax system has been established for thirty years.

The effects on intergovernmental fiscal relations of greater federal reliance on indirect levies would vary markedly with the type of federal levy selected. Any substantial federal expansion in the indirect tax area is likely to accentuate long-standing intergovernmental problems including the availability of revenue sources for the states and tax overlapping. Possible means of avoiding or minimizing these difficulties deserve careful consideration, along with other tax policy objectives, in a determination of the extent and form of federal indirect taxation.

${ }^{109}$ Scripto, Inc. v. Carson, 362 U.S. 207 (1960).

${ }^{110}$ Cf. Dixwell L. Pierce, "State Sales Taxes and Interstate Commerce Can Be Compatible," Proceedings of the National Tax Association for 1961, pp. 339-347.

${ }^{111}$ See Tax Overlapping in the United States 1961, for discussion of the several tax fields. 


\section{COMMENT}

\section{Harvey E. Brazer, University of Michigan}

I believe that it was Gladstone who insisted that direct and indirect taxes should be viewed as equally attractive sisters, neither of whom should be pursued too ardently; rather, governments should pursue both with proper and appropriate grace. My own predilection, however, is to reject the counsel of the great Victorian statesman in this matter. Thus, having decided which of the sisters is more attractive, I should prefer to pursue that sister to greater lengths than Gladstone suggests, while paying only polite attention to the other.

In my discussion of Eldridge's paper I shall concern myself primarily with considerations of equity and intergovernmental relations. Implicit in my discussion is the assumption that indirect taxes are shifted forward. Rather than attempt a point-by-point critique of the Eldridge paper, I shall direct my attention to the issues as I see them.

Turning to the equity question first, it seems to me that if indirect taxes consist of a system of selective excises, whereas direct taxation consists of the personal income tax, there can be little doubt but that the latter is clearly preferable, irrespective of one's index of equality. I do not believe that it is, in fact, possible to achieve any semblance of horizontal equity under a selective excise tax system. It may be possible to do so under a system of general sales taxes, but only if the sales tax is truly general and includes capital goods as well as consumer goods and services in the tax base.

I believe, though, that if one observes the sales taxes as we know them at the state level in this country or at the national level in other countries, he will find that nowhere has it been found to be feasible, or perhaps even desirable, to impose a truly general sales tax. It is true, as well, of course, that no one has found it possible either to levy a truly general income tax, but income taxes appear to approach generality substantially more closely than do sales taxes. It seems to me that the choice between the two in terms of horizontal equity probably depends in large part upon the question of which one it is possible, politically and administratively, to make more general. My guess is that the individual income tax is likely to rank higher on this count.

The choice between a system of excise taxes and the corporate income tax is a more difficult one to make on horizontal equity grounds. If the 
corporate income tax is shifted forward there may be little difference between it and a system of selective excises. In this instance the choice must depend upon the nature of the alternative system of excises. If the excise tax or sales tax system is a general one, and if the corporate income tax is shifted forward, then in terms of horizontal equity the excise tax system appears to be distinctly preferable to the corporate income tax which, of necessity, must vary widely in the ratio of tax to product price.

If the corporate income tax is not shifted forward, an excise tax system which falls considerably short of being general and uniform in its application may still be very much preferable to the corporate income tax which, in this event, turns out to be a discriminatory income tax, at least in the short run and perhaps even in the longer run.

Application of the vertical equity criterion, if one rules out, as I do, the inclusion of the progressive expenditure tax in the definition of possible indirect taxes, clearly leads to a preference for direct taxation in the form of the individual income tax. It may be possible to achieve some degree of progression by means of an excise tax system that relies heavily on so-called luxuries. But then one is reminded of Simons' definition of a luxury as something poor people should do without but won't. In practice it does not really seem possible to rely substantially upon luxury excises as a means of achieving progression in the tax system.

It is possible to achieve some degree of progressivity through the application of a general sales tax, measuring progressivity relative to income. One means of doing so is through the use of a sales tax credit against income tax liability, such as was discussed in staff reports prepared in Minnesota and Wisconsin some years ago and adopted recently in the State of Indiana. Thus, if the sales tax rate is 4 per cent, a credit of $\$ 40$ per taxpayer, spouse, and dependent would provide the equivalent of a $\$ 1000$ per capita sales tax exemption. This device would make it possible to achieve some progression in a sales tax through at least the lower and middle income ranges, but at higher income levels the degree of progression tapers off very rapidly. Moreover, unless the government is willing to give away a very large proportion of the gross receipts of the tax through the use of the credit device, it is unlikely to be possible to achieve much more than rough proportionality, except at low income levels, through the use of the credit.

I do not favor exemption of food and so-called necessities as a means of achieving some degree of vertical equity under a sales tax. Such exemptions necessarily invoke horizontal inequities and, per dollar of revenue cost, are likely to produce less progression than the credit. 
Perhaps the strongest equity argument that can be made in favor of the substitution of excise or sales taxes for a portion of the personal income tax rests on the fact that the income tax is far from general, and to this extent resembles a selective excise tax system. But my own prescription for policy based on the acceptance of this fact does not compound the difficulty through the introduction or extension of excise taxes. It calls, rather, for broadening the personal income tax base.

Turning now to intergovernmental relations aspects of the direct versus indirect taxes issue, one faces the question of the validity of the frequently presented argument against federal entry into the sales tax field that is based on the notion that this field has been pre-empted by the states. I find it difficult to accept this argument in light of the fact that prior entry of the states into a tax field, including such fields as inheritance and estate taxes and the income taxes, has not in the past deterred the federal government from entering it. I see nothing fundamentally wrong with two or even three levels of government taxing the same base. In fact, there are important merits, from the point of view of facilitating administration and compliance, in having two or more levels of government taxing the same base.

The fact that some thirty-seven states now levy retail sales taxes offers some attractive advantages for federal activity in the same area. Among the advantages are the existence of substantial audit experience, taxpayer familiarity with the necessary forms, and a variety of other readymade factors that should aid substantially in achieving a high level of compliance and administration. On the other hand, the entire question of the relative weight of administrative and compliance problems with respect to indirect taxes, as compared with the income tax, is not really at issue. A comparison of the difficulties involved is not relevant because I do not envisage anyone seriously contemplating abandonment of the income tax in its entirety in favor of indirect taxation. Rather, the choice is between adding or not adding indirect taxes to the existing tax structure. It follows, therefore, that the introduction of a new indirect tax or the extension of existing indirect taxes necessarily involves some substantial dead-weight costs, since the administrative and compliance costs involved in adding new taxes to the existing structure are unlikely to be offset appreciably as a consequence of a relative reduction in reliance on the individual or corporate income tax.

The suggestion that the federal government should not enter the sales tax field because of its importance as a source of revenue to the states has relevance only if we have in mind some upper limit beyond 
which we are unwilling to set an over-all sales tax rate. I can clearly see an upper limit beyond which any individual state may find it undesirable to go. For example, a differential in the sales tax rate between Ohio and Indiana of, say, 15 percentage points is likely to have strong adverse effects on the economy of the higher tax state. But the imposition of a federal tax over and above state sales taxes does nothing to increase the absolute differential among jurisdictions in sales tax ratesif anything, relative differentials are reduced through the introduction of a federal sales tax.

To summarize, indirect taxation has little or nothing to commend it relative to direct taxation in the form of the individual income tax. The defects of the income tax, whether they consist of excessive progression or inadequate generality, appear to be more readily susceptible to removal through change in this tax rather than through supplementing it by means of the introduction or extension of indirect taxes. Definition of "direct" and "indirect" taxes offers considerable difficulty, and if the corporate income tax is classified with the direct taxes the choice between it and indirect taxes, particularly if the form of the indirect tax is a value-added tax, is a more difficult one to make on equity grounds. In the area of intergovernmental relations, finally, I can see a host of political problems associated with the federal government's extension of its activity in the area of indirect taxation, but there appear to me to be few, if any, grounds for opposition on the basis of economic, compliance, or administrative considerations.

Ronald B. Welch, Assistant Executive Secretary,

Property Taxes, California State Board of Equalization

I have chosen to leave an analysis of the first section of Eldridge's paper to my colleague from Michigan and to confine my comments on the distributional aspects of direct and indirect taxes to one of the least controversial passages in the section, namely, that "Sales tax burdens are finally distributed in a rather erratic fashion instead of being allocated by the consumption patterns that may be assumed by legislators and others." There is an unsophisticated view of the incidence of sales and special excise taxes that I think is accepted by almost all legislators and tax administrators as well as by a majority of taxpayers. In this view, all taxes on business are passed on in the prices of products. Frequently, indeed, prices are increased by more than enough to shift a tax in full. Such excess shifting, it is held, occurs when excise taxes are imposed at the manufacturers' or wholesalers' level because traditional 
mark-ups are applied to costs of purchases at each succeeding trade level. There may be either excess shifting or incomplete shifting, according to popular opinion, when a sales or excise taxpayer reimburses himself for tax by means of explicit charges to his customers, for it is assumed that the full amount collected from a customer is greater than the amount that would have been collected in the absence of the tax by the exact amount of the reimbursement charged. It may be conceded that persistent shortages will have to be shifted (and this means forward shifting since backward shifting is seldom recognized except by economists), but no recognition is given to the possibility that competition will force sellers to distribute persistent overages to their customers by reducing prices.

This unsophisticated view of tax incidence is seemingly responsible for the prevalence of laws requiring a retailer to remit to the state either the exact amount of sales tax he charges to his vendees or any excess of such amount over the product of his taxable sales and the statutory tax rate. Professor Due forcefully expresses my appraisal of such laws when he says they are among "the most objectionable rules ever developed in sales taxation in the United States." 1 I have never been able to understand why legislators and tax administrators have been content to leave the control of prices of most taxable goods and services to the unseen hand but do not trust competition to squeeze profits out of the small fraction of the total exactions from customers that is labeled tax reimbursement. My point here is that legislative responses to tax proposals are likely to be strongly conditioned by the unsophisticated concepts of tax incidence which I have described.

Eldridge's chapter on administration and compliance contains very little to which I can take exception and a great deal with which I agree. Most of my comments in this area will relate to the sales tax, since I have been more closely associated with its administration than with the administration of any other tax except the property tax.

I have long felt that many of our most baffling problems in sales tax administration arise out of the fact that the tax as we know it in California is short on underlying philosophy. California's outstanding reputation in the administration of its retail sales tax has made its law a model for several other states, so what is true of us is presumably true of others.

Economists have tended to think of general sales taxes as taxes on

${ }^{1}$ State Sales Tax Administration, p. 145. Only about one-third of the states have such rules. 
all personal consumption or alternatively on all personal consumption plus investment. Eldridge has clearly demonstrated how far this ideal concept differs from real life models. Total personal consumption expenditures in California, using national income accounting terminology, were probably slightly in excess of $\$ 42$ billion in 1962 . Our sales tax base was $\$ 26$ billion, but between 25 and 30 per cent was attributable to final sales of producers' goods. Thus, taxable consumer expenditures were probably around 45 per cent of all consumer expenditures in the state. By eliminating exemptions of sales of food for off-premises consumption and of gasoline, we could raise this percentage to around $\mathbf{5 5}$. This would still be a far cry from a tax on all personal consumption, or on all personal consumption plus investment.

The basic scope of our tax, like that of most other state general sales taxes, is sales of tangible personal property other than sales for resale. Why not sales of intangible property? The answer to this question is obvious with respect to so-called "representative" intangibles but not so obvious with respect to patents, copyrights, good will, or a liquor license. ${ }^{2}$ And why not sales of real property $?^{3}$ All kinds of administrative problems are encountered because of this artificial distinction-how to divide a lump-sum price between real and personal property components, how to tax sales of materials that contractors convert from personal to real property, and, in many instances, how to distinguish machinery and equipment which is real property from that which is personal property.

The fact that the sales tax applies to sales of tangible property but not to sales of services is an endless source of controversy. Our earliest lesson in this area was taught to us by those who bought cloth and took it to a tailor for fabrication into clothes. We quickly plugged this loophole, by making fabrication labor taxable. But how does one distinguish fabrication from repair? Recently we have been seeking means of distinguishing between advertising agencies' sales of personal property and their sales of services; no fully satisfactory means have been found, and none ever will be found.

${ }^{2}$ The answer that "nonrepresentative" intangibles are producers' goods is not a sufficient explanation of this exclusion from the sales tax base in a state which uses a final-consumption test rather than a consumer-goods test of taxability.

${ }^{3}$ Due (in State Sales Tax Administration, p. 171) ascribes the exclusion of sales of real property to the desire to avoid the regressivity of a tax on sales of housing on the one hand, and to exclude sales of producers' goods on the other. To these I would add the desire to avoid (1) a large lump-sum tax on a good that yields its services over a long period of time and (2) successive taxes on a property that is frequently sold over and over again. The exclusion of real property sales makes more sense in a state that confines its property tax to real estate than it does in California. 
There is no need to dwell on the illogical distinction which makes sales of consumers' goods for resale exempt and sales of producers' goods for consumption taxable. Whether the distinction eases or increases administrative problems is debatable, though the weight of the evidence appears to favor the former view. Should administrative ease prevail over economic principles? I am not convinced that it should in this instance.

Trade-ins and sales of second-hand goods are treated illogically in most state sales tax laws because the tax has been viewed as a transactions tax rather than a consumption tax. ${ }^{4}$ There is no economic justification for imposing a consumer excise tax on the full value of a durable good more than once during its lifetime. One way to avoid this would be to exempt sales of second-hand goods, but this would create serious administrative problems. A better way, as Due points out, ${ }^{5}$ is to deduct trade-in allowances from the receipts of those taking trade-ins and then tax the subsequent sales of the second-hand goods.

One final problem area with which sales tax administrators are faced arises from the rental of property that would produce a tax liability if sold. Our law provides that rental receipts are subject to the sales tax only (a) when the rental is in lieu of a sale, a phrase which we have interpreted to mean that the property will be substantially worn out at the termination of the lease, or (2) when the property was purchased for resale but is then rented, and the lessor chooses to pay sales tax on the rental receipts rather than use tax on the purchase price. A gap in our law provides that when property is purchased for rental rather than for resale, the tax base is the purchase price rather than the rental receipts.

What I have been suggesting is that many of the problems that sales tax administrators face arise out of the lack of a valid economic distinction between taxable and exempt transactions. Without having been involved in the administration of other types of indirect taxes, I cannot assure you that rationality of tax base and ease of administration are positively correlated, but it seems that they should be.

For this reason, I believe that a value-added tax would be easier to administer than a retail sales tax, save for the fact that it would be applied to a larger group of taxpayers. My thesis is marred by some evidence that the value-added concept is widely misunderstood. When

${ }^{4} \mathrm{I}$ am aware of no theoretical justification for a transactions tax unless it be that such a tax reimburses government for the cost of maintaining a favorable business environment.

5 Ibid., p. 151. 
I was in Connecticut almost thirty years ago, we took a step in the direction of a value-added tax by converting a traditional corporation income tax into a tax on profits, interest, and rent. Unfortunately, the law was drafted by economists who didn't realize that lawyers and administrators would give the rental concept a much broader interpretation than the economics textbooks do. And even when the tax system was surveyed by highly reputed academicians, the survey reports showed no understanding of the purpose of including returns to both borrowed and equity capital in the tax base. ${ }^{6}$ Deduction of rent was reestablished long ago, and the nondeductibility of interest cannot be expected to survive repeated attacks from reputable critics.

Similar misunderstandings of the value-added concept probably account for some of the opposition to the Michigan business activities tax that culminated in the Governor's recent recommendation for repeal. Originally, the law provided for deducting neither capital expenditures when incurred nor depreciation. Later, depreciation on real property but not personal property was made an allowable deduction, thus confronting administrators with the thankless and virtually impossible task of distinguishing the real and personal properties of heavy industry. ${ }^{7}$ While too severe in this respect, the tax law was too lenient in allowing a deduction for all rent and interest payments whether made to taxable firms or to others.

It is unfortunate that we seem destined to have only a short experimental period with the Michigan business activities tax and that the tax base contained such obvious flaws that the experience gained is not a fair test of administrative feasibility. There is no doubt in my mind that this tax contains imposing administrative problems. The sheer number of taxpayers, if nothing else, would make the administrative task much larger in its physical dimensions than that involved in either a corporation income tax or a single-stage sales tax. Offsetting this factor is the certainty that the tax base would be more precisely definable than the income tax base and possibly even more so than a sales tax

${ }^{6}$ Report of the Connecticut State Tax Survey Committee, 1948 (Roswell Magill, Chairman; John F. Sly, Consultant), pp. 129-130; A. G. Buehler, Tax Study, State of Connecticut, March 1963, pp. 163-164. (But see the Minority Report of the 1948 Tax Survey Committee by Joseph M. Rourke, p. 14.) The Connecticut corporation income (franchise) tax is a business tax, not a personal income tax stopped at source. It is associated with a tax on unincorporated business and not with a personal income tax.

${ }^{7}$ Clarence W. Lock, "Administrative History of Michigan's Business Activities Tax," Proceedings of the National Tax Association for 1955, p. 24. 
base. Then, too, as Eldridge observes, a value-added tax could be imposed at a lower rate than politically acceptable income or sales taxes in order to raise a given amount of revenue. Unless the questionable portions of the value-added tax base are larger than those of the alternative tax bases, the incentives for incomplete self-assessment of a low-rate value-added tax will be relatively low and the need for auditing correspondingly less. All in all, I am optimistic concerning the administrative feasibility of a value-added tax. I think it would be somewhat more difficult to administer than a retail sales tax, at least until several years of experience had been gained, but less difficult than a corporation income tax.

The fact that my current responsibilities lie wholly in the property tax field impels me to digress from the subject matter of Eldridge's paper and mention a property appraisal problem that arises from one of the unneutralities of the current federal corporation income tax. This heavy tax on the earnings of equity capital investments has tended to make properties that are so large as to be attractive only to incorporated investors less valuable per dollar of before-tax net income than similar properties that attract unincorporated investors. In valuing a public utility property by capitalizing its earnings, we use earnings before corporation income tax as our amount to be capitalized and include a corporation income tax component in the capitalization rate. ${ }^{8}$ Since the proper size of the income tax component depends upon the relative importance of equity and borrowed capital, we must make rather arbitrary assumptions regarding the capitalization of hypothetical purchasers to estimate what the successful bidder would pay for the property in a market value transaction. We must also draw purely arbitrary dividing lines between properties that are salable only to corporations and those that are salable to individuals. Almost any conceivable revolutionary change in the federal corporation income taxmaking it a personal income tax collected at source, or a tax on earnings available for payments to all capital contributors, or a tax on value added-would ease our property valuation problem.

At the end of his chapter on administration and compliance, Eldridge suggests a low-rate, proportional tax on adjusted gross income as an alternative to an expansion of the scope of federal indirect taxation.

${ }^{8}$ Ronald B. Welch, "Refinements in the Capitalization-of-Earnings Approach to Valuation of Public Utility Properties," Proceedings of the National Tax Association for 1955 , pp. 102-104. 
I have no doubt that this would be more palatable to the state governments. If there has been any tendency at all to separate tax sources, it has been along the lines of federal use of income and sumptuary taxes, state use of general consumption taxes, and local use of property taxes. The states are fairly content to play this role; only a few of the states like New York, Oregon, New Jersey, and Nebraska have firmly resisted the temptation to use broad-based sales taxes as major sources of general fund revenues. The officials of even these states might be expected to lend their voices to the hue and cry that I would anticipate from the other states were a federal sales tax to be seriously debated in the halls of Congress.

It seems to me that the states' resistance would not be appreciably reduced by imposing a single-stage sales tax at the manufacturers' or wholesalers' level. Moreover, there would be great loss in efficiency were the federal government to tax at one stage while the states taxed at another. The two taxes would not differ greatly in their economic impact, but their administration would be so completely different that opportunities for administrative collaboration and for avoiding substantial compliance cost increases would be minimal.

A federal value-added tax, lying somewhat midstream between an income tax and a sales tax, would be less unpalatable to the states. The states have now had nine years in which to watch Michigan's rather clumsy experiment with this tax base, and they have displayed relatively little enthusiasm for it. Michigan's experience may well be on the verge of termination, thanks partly - perhaps mainly - to economic developments that were contemporary with, but wholly unrelated to, this tax. While it has always seemed to me that this tax was better suited to an open economy than to a closed economy, hence better suited to the states than to the federal government, the states have left the base to the federal government by default.

It would be gratifying were I able to close these comments with an expression of hope that the federal government and the states could use the same tax base and integrate their tax administrations. Dr. EckerRacz, I understand, believes that integration is not only possible but probable in the event the federal government enters the sales tax field, but such beliefs are not supported by my observations over the years. Having seen proposal after proposal for desegregation of federal and state tax administration rejected by the state officials and the business community, and equally numerous proposals for more cooperative 
AND INTERGOVERNMENTAL FISCAL ASPECTS

attitudes by the federal government rejected by federal officials (outside the Budget Bureau and the Treasury), I am persuaded that the stone can only be worn away slowly by undramatic actions that fall far short of unified tax administration. 
